Article

\title{
Graduate Employability and Competence Development in Higher Education-A Systematic Literature Review Using PRISMA
}

\author{
Marta Abelha ${ }^{1,2, *(\mathbb{D})}$, Sandra Fernandes ${ }^{2,3}\left[\right.$, Diana Mesquita ${ }^{3}$, Filipa Seabra ${ }^{4}(\mathbb{D}$ \\ and Ana Teresa Ferreira-Oliveira ${ }^{5}$ (i) \\ 1 CEIS20-Centre of 20th Century Interdisciplinary Studies, University of Coimbra, \\ 3000-186 Coimbra, Portugal \\ 2 Portucalense Institute for Human Development, Portucalense University, 4200-072 Porto, Portugal; \\ sandraf@upt.pt \\ 3 CIEC-Research Centre on Child Studies, University of Minho, 4710-057 Braga, Portugal; \\ diana@dps.uminho.pt \\ 4 LE@D, Open University (UAb), 1269-001 Lisboa, Portugal; filipa.seabra@uab.pt \\ 5 CISAS, Escola Superior de Tecnologia e Gestão, Instituto Politécnico de Viana do Castelo, Rua Escola \\ Industrial e Comercial Nun'Álvares, 4900-347 Viana do Castelo, Portugal; ateresaoliveira@estg.ipvc.pt \\ * Correspondence: mabelha@upt.pt; Tel.: +351-962327226
}

Received: 29 April 2020; Accepted: 13 July 2020; Published: 22 July 2020

check for updates

\begin{abstract}
This paper aims to develop a systematic review on graduate employability and competence development, intending to present an international perspective on the matter. It analyses the role of higher education institutions in promoting the development of competences for employability. The Preferred Reporting Items for Systematic Reviews (PRISMA) statement was used as a formal systematic review guideline for data collection. Data was obtained from research studies over the period 2009-2019. The analysis included a total of 69 papers from Web of Science (WoS) and Scopus databases. Results show that Europe leads the number of publications on these topics during the past decade. One of the main issues associated with competence development and graduate employability found in the review is related to the (mis)match between university graduates' competences and employers' needs. Findings indicate that higher education institutions are concerned with using strategies to enhance the development of competences for graduate employability. Graduate employability and competence development around the world depend on a strong sense of innovation and collaboration practices implemented in higher education.
\end{abstract}

Keywords: employability; graduates; competences; higher education; systematic review; PRISMA

\section{Introduction}

Higher education institutions are increasingly expected to engage with the challenges of the contemporary world. Policymakers have repeatedly asked for investment in personal skills as a route to building resilience and aiding recovery following the economic recession of 2008 (e.g., references [1,2]). The industry reinforces this call by requiring professionals who can fulfil the demands of the new contexts and trends, such as the Fourth Industrial Revolution [3].

However, higher education institutions are often criticized for not preparing graduates for the real contexts involved in their professional practice [4]. For that reason, it is not surprising that graduate employability has become one of the central issues that drive the mission of higher education institutions [5]. Thus, several efforts have been made by higher education institutions to meet these identified challenges. For instance, a recent report from the Higher Education Academy [6] 
highlights effective strategies that can be adopted by higher education institutions, gathered from existing literature, in order to embed employability into institutional initiatives—namely, development and/or consolidations of services for institutional career guidance; reinforcing employability through curricula (e.g., entrepreneurship courses) and extracurricular activities (e.g., volunteering activities); encouraging networking that enables the students to interact with employers and real experiences in the labour market (e.g., mentoring programs); supporting students in their personal development (e.g., self-confidence); and encouraging international mobility and critical thinking regarding their learning experiences as a whole. In summary, these kinds of initiatives allow higher education institutions to develop an institutional narrative based on employability [7]. Additionally, these are initiatives that intend to adequately prepare the graduates for their professional practice, which is directed towards an environment of uncertainty and constant change [8].

In order to facilitate shared understanding, it is essential to address some assumptions about the concept of employability. There is a lack of clarity about what employability means [6]. For instance, some authors assume the complexity of the concept, identifying seven different perspectives about employability [9]. More recently, some authors have argued for the need of an integrated overview, which takes into account the specification of different contexts, cultures, and countries $[5,10,11]$.

In the context of higher education, employability is considered more than merely 'getting a job' [12], as it implies 'a set of achievement—skills, understandings and personal attributes—that makes graduates more likely to gain employment and be successful in their chosen occupations, which benefits themselves, the workforce, the community and the economy' (p. 8) [13]. This perspective is aligned with the approach presented by Römgens, Scoupe, and Beausaert [11], in which defining employability includes a competence-based dimension. In other words, the focus is based on the identification and development of knowledge, competences, and attributes that foster students' development of effective performance in the labour market. This perspective also reinforces the responsibility of higher education institutions in the quality of the routes followed by their students.

A competence-based approach to employability also implies the discussion of what competence means. Several studies approach this term under different perspectives and using different words, such as abilities, knowledge, skills [14]. This idea is reinforced by Ashworth and Saxton [15], stating that 'it is not clear whether a competence is a personal attribute, an act, or an outcome of action' (p. 3). Thus, competence is a problematic concept [16]. This discussion is not new, but still necessary when considering the central role of competences in the context of higher education. This is one of the reasons why competences and employability are interrelated concepts. With this in mind, a broad perspective about competence will be considered, taking into account the following five main conceptual dimensions:

1. Competence refers to people who have a previous background (knowledge, skills, abilities, past experiences, beliefs, values, etc.) that might be called resources [17,18];

2. Competence implies the mobilization of those resources in a specific context (e.g., solve a problem) [19];

3. Competence is visible inside of a particular context, in which it is possible to identify which competences people need to develop [20];

4. Competence requires more than the acquisition of knowledge [18]; it is also more than a skill (something that a person is able to do) [21];

5. Competence is a complex term, and some authors organize it in categories to provide a greater understanding of methodological issues [22].

Thus, these perspectives about competence and employability underlie the aim of this study, which intends to develop a systematic review in order to understand which competences are being associated with graduate employability and how pedagogical practices can support the development of competences for employability. To attain this goal, the following research questions were defined: 
(1) What are the main research issues related to competence development and graduate employability?

(2) Are competences being associated with graduate employability? Which ones? How is higher education fostering student competences for employability?

In the analysis of these dimensions, a worldwide perspective will be considered and, therefore, a third research question was included:

(3) Is there international concern about this topic or, is it mainly European and Anglo-American? Are there specificities in different continents?

The following section presents a detailed description of the research methodology, including a rigorous explanation of the procedures for data collection and analysis.

\section{Methodology}

We followed the Preferred Reporting Items for Systematic Reviews (PRISMA) guidelines [22] to produce this review. Systematic reviews often present a lack of awareness of shared guidelines that make them replicable and scientifically adequate. PRISMA provides a standard peer accepted methodology that uses a guideline checklist, which was strictly followed on this paper [23-25], to contribute to the quality assurance of the revision process and to its replicability. A review protocol was developed, describing the article selection criteria, search strategy, data extraction, and data analysis procedures.

\subsection{Data Sources and Search Strategies}

We systematically searched two electronic databases (Web of Science and Scopus) between the years 2009 and 2019. These are the two most highly valued databases for the Portuguese scientific system (for evaluation and funding), which is why they were used in our study. We identified peer-reviewed studies with articles written in English and Spanish. Databases were searched separately by two of the researchers (M.A. and S.F.). To identify as many eligible studies as possible, we broadened search terms and strategies. Search terms were modified together with informatics and combined with Boolean operators as follows. The terms "competences* AND" skills*AND "higher education*AND" employability*AND "graduates" as keywords for the topic (WoS), article title, abstract, and keywords (Scopus). The reference lists of the eligible articles included after the electronic search were also manually searched.

\subsection{Selection of Studies}

Titles and abstracts were reviewed independently by two of the researchers (M.A. and S.F.) who used the abovementioned criteria to determine paper eligibility to be included in the study. The full text of potentially relevant studies was reviewed for final inclusion. All discrepancies were resolved by consensus with one of the researchers (A.T.F.O., D.M., or F.S.).

\subsection{Data Extraction Data Extraction Process and Quality Assessment}

Data extraction and article quality assessment were performed by three researchers independently. Data extracted from each study were recorded in an evidence table. The five authors of the paper (M.A., S.F., D.M., F.S., and A.T.F.O.) collected data from primary studies. Any discrepancies were solved by consensus between the reviewers.

\subsection{Eligibility Criteria}

The selection of the articles to review was conducted in three rounds. The first round of analysis was the screening of the title and abstract in which three reviewers were involved. The second round was the analysis of the articles by five reviewers, independently. The selection criteria were established according to the research question, and the results were organized in a table. We eliminated studies 
with no full text available. In the third round, a single reviewer read and integrated all results in a single document. Articles in this round were retrieved for a comprehensive examination in order to decide inclusion in our study. To address our specific research questions, we excluded all papers that did not describe research examining the process and outcomes of competence development related to graduate employability.

\subsection{Constitution of the Corpus of Analysis}

The listed studies were organized by year of publication and by alphabetical order of the first author's name. The articles were coded with a number. The thematic content analysis of the articles was based on strategies and procedures developed by Bardin [26].

The search based on the inclusion criteria yielded a total of 99 articles. After the application of exclusion criteria (Figure 1), we narrowed this number to a total of 69 articles relevant to the present systematic review of the literature. Three articles did not directly contribute to our research questions and were therefore excluded $(n=3)-9 S, 10 S, 38 \mathrm{~W}$.

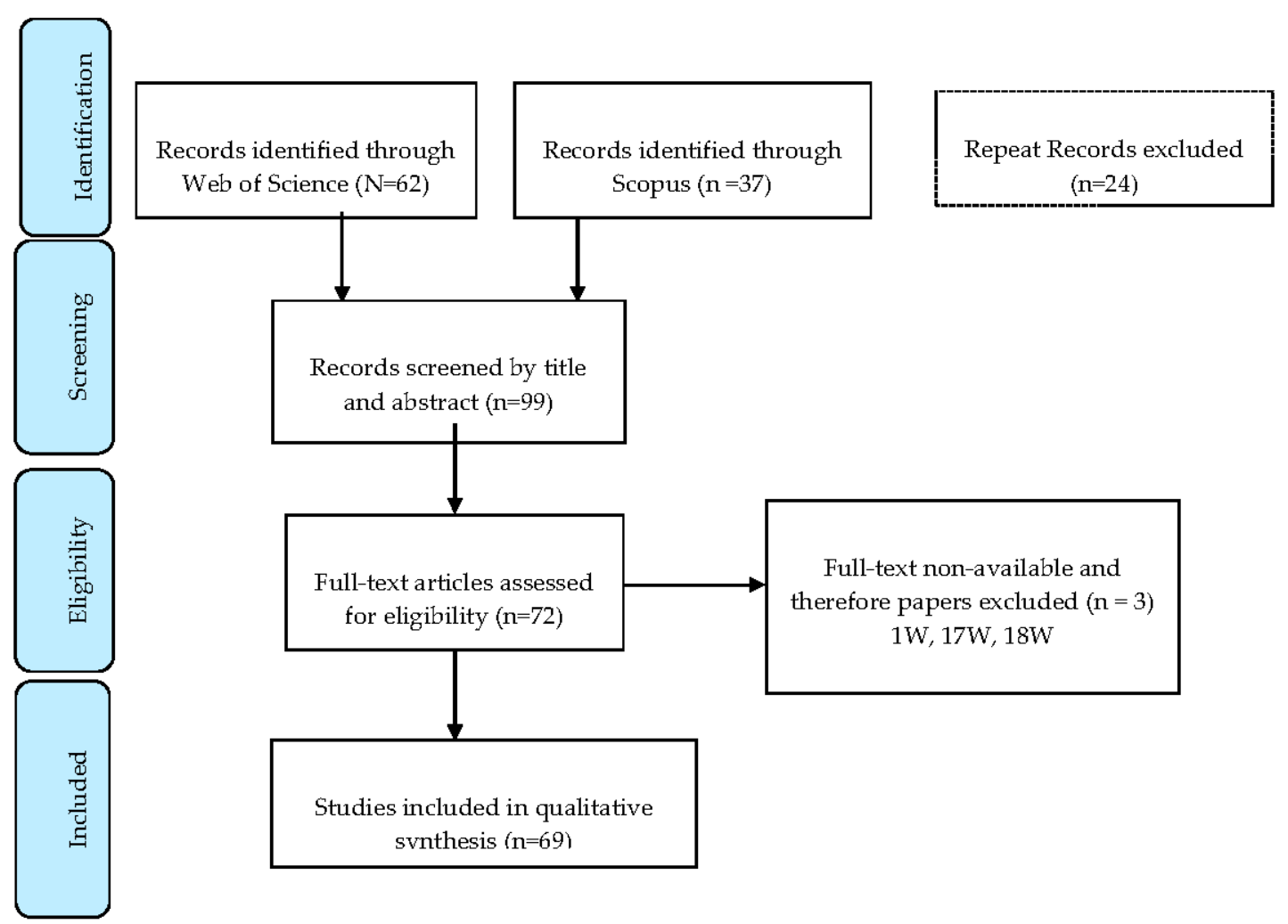

Figure 1. Reporting items for the systematic review (adapted the Preferred Reporting Items for Systematic Reviews (PRISMA) statement).

Appendix A presents all the papers included in the systematic review $(n=69)$ and the codification (number of the paper and its database ( $\mathrm{S}=\mathrm{Scopus}$; $\mathrm{W}=$ Web of Science) used to identify each one of the papers, which will be used in the next section to discuss the results of the analysis.

\subsection{Characteristics of Included Studies}

The year with more studies that entered our search is 2019, as depicted in Figure 2. Our results show a relevant increase in the number of published studies in the last four years. 


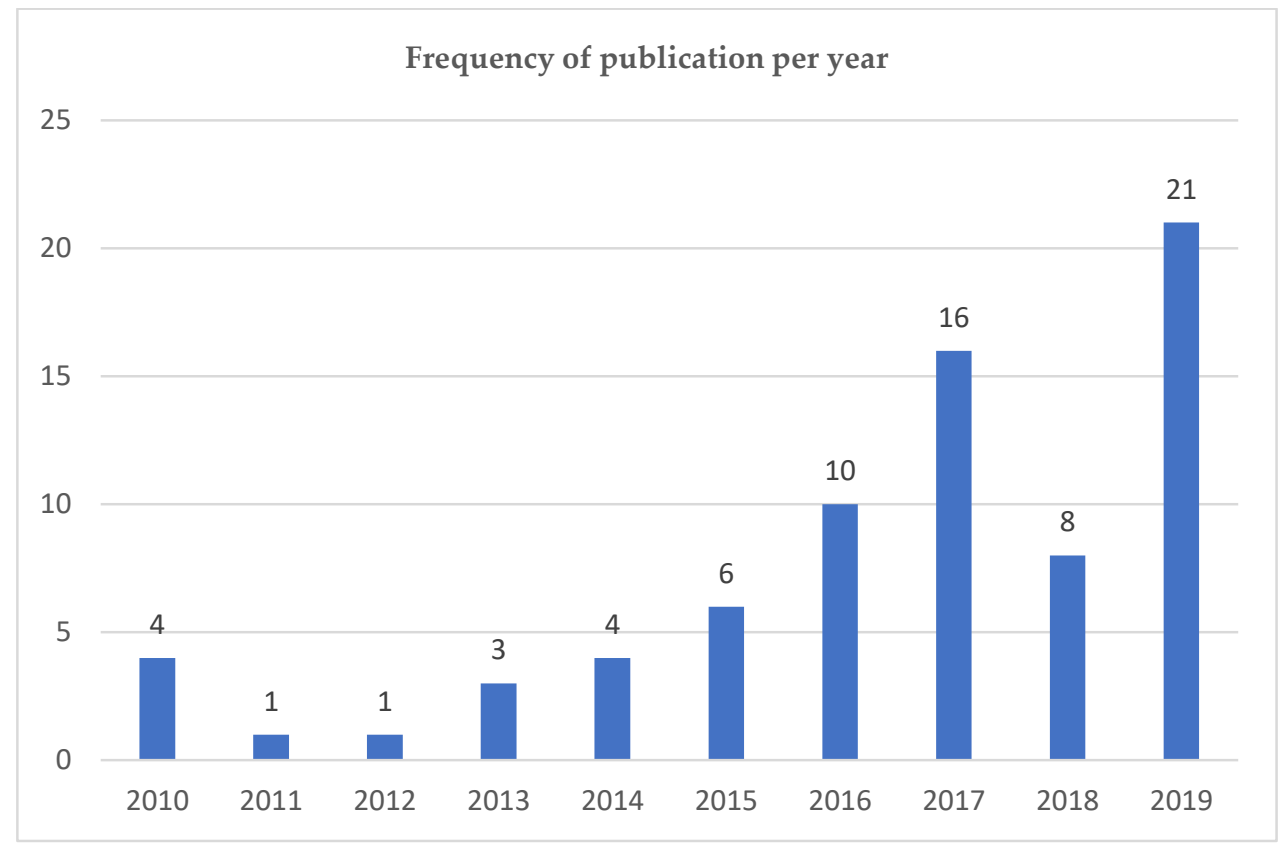

Figure 2. Frequency of publication per year.

Regarding the methodology, we have found a predominance of quantitative studies $(n=$ 32). However, the distribution among qualitative and mixed methods studies is very balanced, with qualitative studies presenting 22 results and mixed methods studies showing 15 results.

Regarding the journals that are publishing under this topic, 51 different journals published on the subject under analysis, which reveals the enhanced relevance of the theme in various areas of knowledge. Figure 3 presents journals with more than one paper dedicated to the issue under analysis.

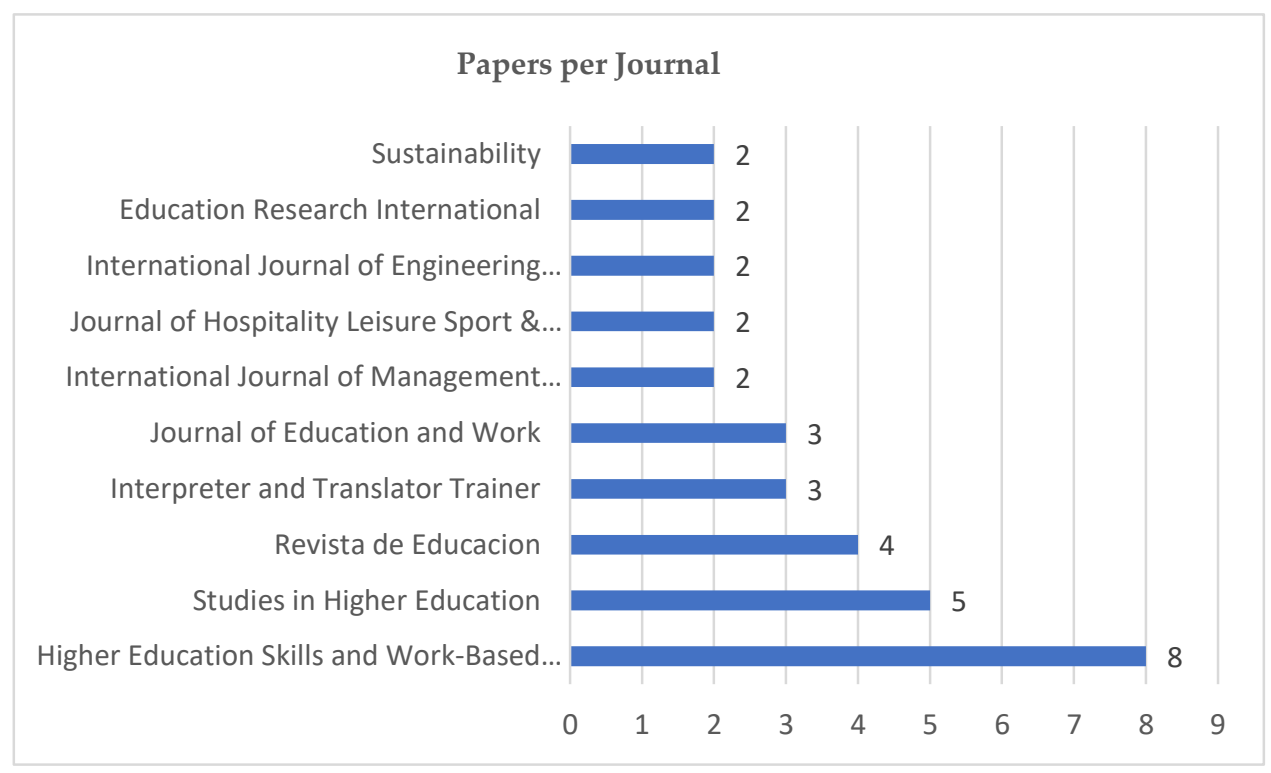

Figure 3. Frequency of papers per journal.

The main fields of knowledge focused upon by published studies are those of engineering, management, accounting, marketing, business, and administration. Some of the other specific fields included in the studies are nursing, statistics, industry, vocational education, hospitality, English, psychology, pedagogy, education, information technology, sports, translation, and, finally, geography. There are also several studies that do not focus on a specific area of knowledge and that refer to 
higher education graduates in general. On the other hand, other studies encompassed multiple fields of knowledge.

The following table (Table 1) shows the different areas of knowledge that are focused on by the publications included in our search results.

Table 1. Number of papers by field of knowledge.

\begin{tabular}{cc}
\hline Field of Knowledge & N \\
\hline Engineering & $\mathrm{N}=10$ \\
\hline Management, Accounting, Marketing, Business Administration & $\mathrm{N}=10$ \\
\hline Hospitality & $\mathrm{N}=04$ \\
\hline Psychology, Pedagogy, Education & $\mathrm{N}=03$ \\
\hline Translation & $\mathrm{N}=03$ \\
\hline Geography & $\mathrm{N}=03$ \\
\hline Nursing & $\mathrm{N}=02$ \\
\hline Statistics & $\mathrm{N}=02$ \\
\hline Industry & $\mathrm{N}=01$ \\
\hline Vocational Education & $\mathrm{N}=01$ \\
\hline English & $\mathrm{N}=01$ \\
\hline Information Technology & $\mathrm{N}=01$ \\
\hline Sports & $\mathrm{N}=01$ \\
\hline Multiple areas & $\mathrm{N}=09$ \\
\hline No specific field of knowledge identified & $\mathrm{N}=21$ \\
\hline & 74 \\
\hline
\end{tabular}

\subsection{Strengths and Limitations}

In this review, we used PRISMA methodology, and we tried to identify as many eligible studies as possible. We broadened search terms, databases, and resolved any discrepancies through active discussion. Despite the fact that we intended to convey an international dimension to our analysis, we chose to limit our search to two databases acknowledged by their quality and contribution to science in order to guarantee the rigor and quality of the studies included in our review. We prioritized the quality assurance of the papers selected over the breadth of the analysis-however, this led to a selection of only 69 papers representing 27 countries. Considering this output, doubt emerges if, by including other databases, more studies from a broader selection of countries might not have been included.

\section{Results}

In this section, we present the results found through the aforementioned systematic revision process, organized according to the research questions that guided our search and analysis.

3.1. What Are the Main Research Issues Related to Competence Development and Graduate Employability? Are Competences Being Associated with Graduate Employability? Which Ones? Can These Competences Be Assessed and Developed?

- Match or Mismatch between University Graduates' Competences and Employers' Needs [(3W), (5W), (7W), (10W), 23W, (28W), (41W), (48W), (49W), (53W), (55W), (56W), (58W), (60W) (1S), (5S), (11S)]

One of the main research issues associated with competence development and graduate employability found in the systematic review carried out is the (mis)match between university 
graduates' competences and employers' needs. For example, the purpose of paper $3 \mathrm{~W}$ is to examine the work-readiness competences of Australian higher education (HE) and vocational education (VE) graduates. The authors want to know which competences are considered to be lacking in Australian graduates, what are the likely causes of these competence deficits and how these competences can be developed to improve graduate work readiness outcomes. The purpose of paper $5 \mathrm{~W}$ is to identify a widening gap in 'global operating skills' and put forward a structure for addressing the education-job mismatch, based on data gathered from higher education teachers and graduate recruiters. The purpose of paper 7W was to investigate the incorporation of professional skills into Greek accounting education studies. It was driven by complaints from employers and other stakeholders that Higher Education is not keeping pace with global trends in the economy.

The aim of the empirical analysis presented in paper 10W was to identify competences that are key in determining the probability of graduate recruitment. It aimed to analyse the employability traits of engineering graduates who had recently graduated and identify which competences act as a stimulus for employment and which discourage hiring. Paper $23 \mathrm{~W}$ analyses which competences should be regarded as more important by graduates and universities to meet the expectations of employers in the psycho-educational sector. Given that there is significant overlap between employability skills, generic graduate attributes and sustainability capabilities, paper $28 \mathrm{~W}$, has relevance beyond the measurement of sustainability capability to include the measurement of uptake and professional application of generic capabilities more broadly. Paper $41 \mathrm{~W}$ analyses the impact on the employability of recent graduates and the potential mismatches between their skills and the competences required by the job structure. Paper $48 \mathrm{~W}$ aims to discuss the impact of competence and skills learned in the university with skills demanded in the workplace. Paper $49 \mathrm{~W}$ identifies the mismatch between the demand for academic knowledge and the professional demand in the work life and draws policy implications on the findings. The authors of paper $53 \mathrm{~W}$ defend the adjustment of the competence profile acquired by the graduate with the business network needs. Paper $55 \mathrm{~W}$ examines the level of competence achieved by nursing students and the level of competence required by employers. Paper 56W proposes to analyse the existence of a gap between market requirements and education concerning students' digital competence level, and possible mismatches by sex and field of knowledge.

Paper 58W aims at analysing skills and competences acquired by students during their university studies, to identify the extent to which they fit into the labour market demands. Paper $60 \mathrm{~W}$ argues that it is necessary to discover what employers demand from graduates, what education and training graduates have when they start a new job and what aspects could be improved from the employers' point of view. Paper $5 S$ explores what skills and qualifications the companies are asking for among their personnel. By doing this, it is possible to find areas that could be improved in the existing engineering education programmes in the Vaasa region. Paper 11S examines the relationship between university education and labour market needs.

In general, the findings of the studies under analysis point out the need for higher education institutions to meet the needs of the labour market, generally acknowledging the existence of a mismatch between the competences developed in higher education and those that are favoured by employers. Nevertheless, efforts towards aligning the needs and expectations of potential employers and the curricula of the programs under analysis are also recognized. We also point out a critical concern about the roles that the market should assume in the definition of higher education curricula. If it is undeniable that concerns about employability are pressing and meeting the demands of employers is a necessary route toward promoting the ready insertion of graduates in the labour market, one cannot forget that academia is more than a promotor of employability. Moreover, market demands are rapidly shifting, and intending to meet market requirements rather than acting proactively and preparing adaptable and critical professionals may have detrimental results. Stressing the importance of developing higher-order skills, even if not immediately sought for by employers, remains relevant. An open and continued dialogue between academia and employers, with two-way contributions, may prove a worthy undertaking. 
- Undergraduate self-perceived employability [(15W), (23W), (33W), (36W), (44W) (54W) $(59 \mathrm{~W})(4 \mathrm{~S})]$

Paper 15W focuses on undergraduate self-perception of employability. Understanding the students' self-perception of graduate employability is essential to highlight areas of agreement or potential mismatch with perceptions of other stakeholders. Paper $23 \mathrm{~W}$ explores which competences should be regarded as more important by graduates and universities to meet the expectations of employers in the psycho-educational sector. Paper $33 \mathrm{~W}$ focuses on the individual dimensions of perceived employability and explores perceptions among undergraduates and the associated influence of career management competences, work experience and individual characteristics. Paper 36W explores undergraduate students' perception of employability in the field of translation and interpretation. Paper $44 \mathrm{~W}$ focuses on searching for variations in employability experiences and demand by graduates across generations, in different disciplines and by gender. Paper $54 \mathrm{~W}$ intends to contribute to a graduate-centred understanding of work-readiness and map students' perceptions and evaluations of their skill development in criteria referenced graduate capabilities. Paper 59W presents the views of undergraduates and aims to know whether undergraduate students are engaged with the development of employability skills. Paper $4 S$ aims to understand the gap between students' and employers' perceptions of the major competences required by the job market. The research results showed that students stressed the general competence dimension more, which comprised language and communication competence and information and technological competences, while employers attributed greater importance to the personality dimension.

As results appear to reveal differences between students' self-assessment and the assessment of employers, these studies contribute to rethinking higher education curricula, in order to promote both students' employability and more realistic self-assessment of employability by students. This may assist students in intentionally developing the competences they most need.

\section{- Development and validation of an instrument [(9W), (3S), (27W), (32W), (53W)]}

Out of the 69 papers analysed, five focus on the development and validation of an evaluation instrument (9W; 27W; 32W; 53W; 3S). Some of these scales are specific for graduates in certain knowledge areas, while others are targeted to higher education students in general $(9 \mathrm{~W})$. For example, the purpose of paper $9 \mathrm{~W}$ is to develop a scale to measure students' life ability skills, which include the following: teamwork, goal setting, time management, emotional skills, interpersonal communication, social skills, leadership, and problem-solving and decision making. Paper $3 S$ reports the assessment of university students' oral communication competence through a reliable and valid scoring rubric. Paper 27W evaluates an assessment tool, based on a scenario/vignette question design, which can be used to capture data on graduate sustainability attributes in context and has the potential to be used across a large graduate population, which would enable comparative research of learning outcomes to be undertaken. The paper focuses on the assessment of the following five competences: (1) recognising interrelationships (requiring awareness and knowledge), (2) appraising and critiquing measures, (3) applying environmental and sustainability literacy, (4) taking responsibility for decision making, and (5) providing leadership. The purpose of paper $32 \mathrm{~W}$ was to identify skills needed in the workforce in the field of sports and recreation in a Greek sample of employers. In paper 53W, using the Delphi Method, the authors propose a generic competences model, from which they obtained the minimum desired graduate profile in these competences for the labour force in that zone.

The papers included in this category are relatively few, which stresses the need for the development and validation of instruments for the assessment of competences for employability. The instruments they present are diverse, both in terms of methodological approach and of the competences which are appraised, which can be perceived both a strength, since multiple perspectives are considered, and as a weakness, as an inter-studies analysis is challenging.

- Transition to practice and the role of internships [(6W), (14W), (51W)] 
Internships play an important role for competence development and graduate employability. This is confirmed by some of the studies found in our search, although this concerns a relatively small number of studies. Paper $6 \mathrm{~W}$ seeks to contribute to sustainable approaches regarding curricular internships in higher education of first-cycle degrees (corresponding to undergraduate degrees, within the Bologna Process). On the one hand, it aims to understand the internship processes ranging from the planning to the implementation stages. On the other hand, it elicits the associated negative aspects (the lunar side) of internships, allowing for an assessment of the features where there is room for improvement (6). Another study, paper 14W, looks at employers' perspectives about internships and the opportunities and difficulties in conducting internships in higher education. The purpose of paper 14 is to identify employers' opinions on the possibility of organizing and capitalizing on internships for students from Vasile Alecsandri University of Bacau (UVAB) in Romania. Paper 51W states that there is a broad acknowledgement about the value of internships, which are seen as an opportunity to improve work-related skills.

Internships are presented as a prominent avenue for the development of work-related competences, despite the existence of some challenges to their implementation. They are a pertinent way of promoting the interaction between academics, students, and employers. The relevance of internships for the transition to practice appears worthy of further inquiry.

- Development of specific skills [all papers]

Another issue arising from our analysis is that some papers focus specifically on specific competences, that may be either technical or transversal, referred to in some studies as 'soft skills'. More specifically, the following skills were identified, according to two main categories, as presented in Table 2.

Table 2. Categorization of skills analysed by papers.

\begin{tabular}{|c|c|c|}
\hline Technical Skills & Paper \# & $\mathrm{N}$ \\
\hline \multirow[t]{2}{*}{ Solid technical background } & $5 \mathrm{~S}, 12 \mathrm{~S}, 24 \mathrm{~W}, 26 \mathrm{~W}, 30 \mathrm{~W}, 37 \mathrm{~W}, 60 \mathrm{~W}$ & 7 \\
\hline & Total & 7 \\
\hline Transversal Skills & Paper \# & $\mathrm{N}$ \\
\hline Communication skills & $1 \mathrm{~W}, 3 \mathrm{~S}, 5 \mathrm{~S}, 8 \mathrm{~W}, 8 \mathrm{~S}, 11 \mathrm{~S}, 24 \mathrm{~W}, 26 \mathrm{~W}, 30 \mathrm{~W}, 32 \mathrm{~W}, 39 \mathrm{~W}, 40 \mathrm{~W}, 42 \mathrm{~W}, 43 \mathrm{~W}, 50 \mathrm{~W}, 58 \mathrm{~W}$ & 16 \\
\hline Emotional Intelligence skills & 5S, 12S, 11W, 24W, 25W, 31W, 32W, 34W, 37W, 46W, 53W, 60W,62W & 13 \\
\hline Teamwork & 1S, 23W, 24W, 26W, 30W, 37W, 42W, 43W, 46W, 52W, 54W & 11 \\
\hline Soft skills (in general) & $12 \mathrm{~S}, 13 \mathrm{~S}, 13 \mathrm{~W}, 31 \mathrm{~W}, 32 \mathrm{~W}, 37 \mathrm{~W}, 40 \mathrm{~W}, 42 \mathrm{~W}, 53 \mathrm{~W}$ & 9 \\
\hline Computer skills/Digital Competences & $2 \mathrm{~S}, 11 \mathrm{~S}, 40 \mathrm{~W}, 46 \mathrm{~W}, 56 \mathrm{~W}, 60 \mathrm{~W}$ & 6 \\
\hline Entrepreneurship skills & $1 \mathrm{~S}, 12 \mathrm{~W}, 37 \mathrm{~W}, 42 \mathrm{~W}, 58 \mathrm{~W}$ & 5 \\
\hline Organization \& Time Management & $1 \mathrm{~S}, 25 \mathrm{~W}, 32 \mathrm{~W}, 34 \mathrm{~W}, 43 \mathrm{~W}$ & 5 \\
\hline Problem solving & $24 \mathrm{~W}, 25 \mathrm{~W}, 30 \mathrm{~W}, 32 \mathrm{~W}, 43 \mathrm{~W}$ & 5 \\
\hline Leadership & $25 \mathrm{~W}, 26 \mathrm{~W}, 50 \mathrm{~W}, 58 \mathrm{~W}, 60 \mathrm{~W}$ & 5 \\
\hline Critical thinking & $1 \mathrm{~S}, 24 \mathrm{~W}, 25 \mathrm{~W}, 43 \mathrm{~W}$ & 4 \\
\hline Intercultural communication Skills & $1 \mathrm{~S}, 5 \mathrm{~S}, 8 \mathrm{~W}$ & 3 \\
\hline Creativity & $24 \mathrm{~W}, 37 \mathrm{~W}, 43 \mathrm{~W}$ & 3 \\
\hline Career management competences & $31 \mathrm{~W}, 33 \mathrm{~W}$ & 2 \\
\hline Learning skills & $1 \mathrm{~S}, 34 \mathrm{~W}$ & 2 \\
\hline Community and citizenship knowledge & $25 \mathrm{~W}$ & 1 \\
\hline Information and communication literacy & $25 \mathrm{~W}$ & 1 \\
\hline Decision making & $30 \mathrm{~W}$ & 1 \\
\hline Research skills & $43 \mathrm{~W}$ & 1 \\
\hline
\end{tabular}

For example, paper $13 \mathrm{~W}$ aims to explore graduate students' perception of how soft skills are developed at a transnational university in Vietnam and how these soft skills contribute to their perceived 
employability. Paper $4 \mathrm{~S}$ aims to understand the gap between students' and employers' perceptions of the foremost competences required in the job market. The research results showed that students stressed the general competence dimension more, which comprised language and communication competence and information and technological competences, while employers put more importance on the personality dimension. Paper $25 \mathrm{~W}$ aims to explore students' perceived importance of generic skills in the engineering and business disciplines. Paper 26W explores students' perception of technical accounting knowledge, teamwork, leadership and communication skills.

We note that the majority of the studies under analysis focus on 'soft' skills-either in general or in particular. Fewer studies look specifically at technical skills-this, however, does not mean these are less important, but rather that they seem to be classically the core of higher education institutions' concern, and therefore may not be as pressing a matter. A wide variety of competences is considered necessary, which presents a challenge to higher education institutions and may guide the rethinking of curricula.

In summary, in Section 3.1, we looked for the primary research issues related to competence development and graduate employability present in the corpus of analysis. Some topics stood out-namely, the (mis)match between university graduates' competences and demands of the workplace; the self-perceived employability of undergraduates; the transition from academia to the workplace, stressing the role of internships; and employability among specific fields of knowledge, most prevalently those of management, accounting, business, and administration.

Looking into the specific skills that were analysed by the studies, it is possible to identify a focus on transferrable (or 'soft') skills (including 16 papers related to communication skills, 13 to emotional intelligence, 11 to teamwork, nine to soft skills in general, and six to digital competences, among other less researched competences identified in Table 2), coupled with a stress on technical skills (seven papers, as identified in Table 2).

The assessment of these competences is an area requiring further study, as will be further developed in the Discussion section, despite the fact that five studies are also concerned with the development and validation of instruments (9W, 3S, 27W, 32W, 53W).

\subsection{How is Higher Education Fostering Student Competences for Employability?}

Several papers (20 out of 69) are concerned with the strategies that Higher Education Institutions can use to enhance the development of competences for graduate employability (4W, 16W, 19W, 22W, $29 \mathrm{~W}, 30 \mathrm{~W}, 34 \mathrm{~W}, 35 \mathrm{~W}, 39 \mathrm{~W}, 45 \mathrm{~W}, 47 \mathrm{~W}, 57 \mathrm{~W}, 61 \mathrm{~W}, 62 \mathrm{~W}, 1 \mathrm{~S}, 6 \mathrm{~S}, 7 \mathrm{~S}, 8 \mathrm{~S}, 11 \mathrm{~S}, 12 \mathrm{~S})$. Paper $4 \mathrm{~W}$ examines the curriculum and pedagogic requirements that contribute to beneficial graduate outcomes for Australian hotel management students. The added value of paper $16 \mathrm{~W}$ lies in adopting a learner-centred, genuine, and effective learning approach, such as authentic learning as a catalyst for bringing work experience to formal education in higher education institutions, to better develop graduates' employability skills. Paper 19W explores work-based learning (WBL), one of the platforms for students to gain actual working experience in addition to developing career management competences to prepare for starting a career. The purpose of the study is to explore the career management competences that students can master through WBL. Paper 34W questions the extent to which academic performance, in terms of grade point average (GPA), combined with the participation in extracurricular activities (ECAs), can raise the perceived employability of graduates and, in particular, whether ECAs may overcome or compensate for poor academic performance. Paper $22 \mathrm{~W}$ focuses on the creation of professional degree programmes as an operational strategy for enhancing graduate employability.

As a consequence of the conceptualization and operationalization strategies adopted, we identified mismatches between policy objectives and policy outcomes. Paper $29 \mathrm{~W}$ stresses that higher education institutions could embed the concept of employability in the learning programme design process and into learning, teaching and assessment practices. Employability could be further enhanced by incorporating work experience in the curriculum, by building an institutional culture that promotes employability and by inviting employers as guest lecturers. Paper 30W identifies eighteen (18) aspects 
for program assessment to be integrated in higher education curriculum design/development to enhance graduates' employability. Paper 35W presents a reflective exercise for how an institution can embed employability skills in the curriculum and facilitate the transition of Translation graduates into the workplace. Paper $39 \mathrm{~W}$ considers how content and language-integrated learning (CLIL) is expected to develop learners' cognitive flexibility, communication skills, meaningful interaction, skills for working life and intercultural awareness, and thus equip them with enhanced mobility and employability for the labour market. Results show that CLIL can facilitate learners' local integration, cultural awareness, open-mindedness, flexibility, global vision, and ultimately graduates' mobility and employability. Paper 45W's findings will benefit the career development of hospitality graduates and the validation of universities' hospitality curricula as it examines how experiential learning (EL) activities influence the employability skills of entry-level hotel employees/graduates and their resulting learning satisfaction. The results show that EL is positively associated with employability skills, hence reinforcing the pertinence of including EL activities within the curricula.

Paper $47 \mathrm{~W}$ aims to empirically verify the impact of educational capital on the success or failure of higher education graduates' transitions, and questions which components of educational capital determine the status (working/unemployed) of recent HE graduates in the job market. Paper 57W intends to review live-client learning activities in higher education, highlighting a lack of multi-stakeholder evaluation of 'learning by doing' pedagogies in current literature. Paper 61W describes how German geography graduates find that they experience a deficit regarding the teaching of competences. The competence deficit can be overcome, first, by helping graduates focus more on their future during their education and, second, by relating the curriculum more closely to conditions in the labour markets for geographers. Paper $62 \mathrm{~W}$ identifies the personal skills map and employability factors. This study analyses their assessment in two comprehensive samples of university graduate students. It identifies areas and strategies of formative action where universities may improve their graduate's employability through employability auditing, the design of training programs or different activities within professional guidance and tutorship planning programmes. Paper $1 \mathrm{~S}$ aims to illustrate practical strategies higher education practitioners are using to address the 'skills gap' deplored by employers and industry. How are teachers in institutes of technology and polytechnics embedding employability skills into their teaching practices? This paper describes how a sample of experienced teachers in Aotearoa, New Zealand, is currently integrating ways of enhancing the employability of their students into curricula. Paper $6 \mathrm{~S}$ presents and tests a model of undergraduate competence in employability skills. It highlights those factors which impact on competence in employability skills and identifies ways in which stakeholders can adjust curricula and pedagogy to enhance graduate skill outcomes. Paper 7S recommends that hospitality management academics and employers take note of the vital curriculum and employability implications the study can have on the development of hospitality management graduates. Paper $8 \mathrm{~S}$ aims to address the issue of communicative competence among higher education students. It focuses specifically on how adequately linguistic, pragmatic, and communicative skills are taught in higher education institutions' language programs. The researchers recommend that these skills be integrated into content-based courses throughout the different majors' study plans. Paper 11S's results may guide action in the current design of new degrees when dealing with these skills, with practical implications for higher education and engineering curriculum design related to the enhancement of graduate employability.

In summary, in Section 3.2, we analysed the documental corpus in terms of how higher education institutions (HEIs) are promoting competences for employability. It is clear that the promotion of competences for employability is a concern for HEIs, and that studies are addressing that concern. A dimension that appears to be relevant is the debate about which strategy is best to address this subject, be it by embedding this concern into the curriculum of undergraduate programs, offering optional extracurricular programs or focusing on the development of competences that can take place in work context experiences. None of the studies provides a unanimous answer to this question, which, as further analysed in the Discussion section of this paper, still requires additional inquiry. 
3.3. Is There a Worldwide Concern about This Topic, or is it Mainly European and Anglo-American? Are There Specificities Worldwide?

A first look at the results clearly identifies Europe as the continent where most of the research on these topics has originated over the past decade. Among the papers selected, 36 are based on studies conducted in ten European countries (Spain, the United Kingdom, Portugal, Finland, Sweden, Greece, Poland, Germany, Romania, and Slovenia), 14 are based on studies conducted in 10 Asian countries (India, Taiwan, Malaysia, Vietnam, Oman, China, Russia, Qatar, and Hong Kong), eight are based on studies carried out in two countries in Oceania (Australia and New Zealand), four based on studies in four African countries (Ethiopia, Cameroon, Tanzania, and South Africa), and one is based on a study carried out in North America (USA). One of these papers is based on an analysis of both the UK and Australia, and therefore is counted in both countries and respective continents, and one paper is based on an analysis of three European countries-Spain, Germany, and Sweden-and is therefore counted in those three countries, but only once for the European continent.

Four countries are studied in more than two of the selected papers, three of which are in Europe: Spain visibly stands out with 16 papers, the UK and Australia are studied in seven papers each, and Portugal is studied in three papers. The distribution of papers in Europe does not clearly depict a north/south axis, as might be expected. America is the least represented continent, and the absence of papers from South America is noted. The data therefore depicts not a European and Anglo-American predominance but rather a European, Asian, and Oceanian prevalence, with a smaller presence of African studies and a near absence of American studies. These data are illustrated in Figure 4.

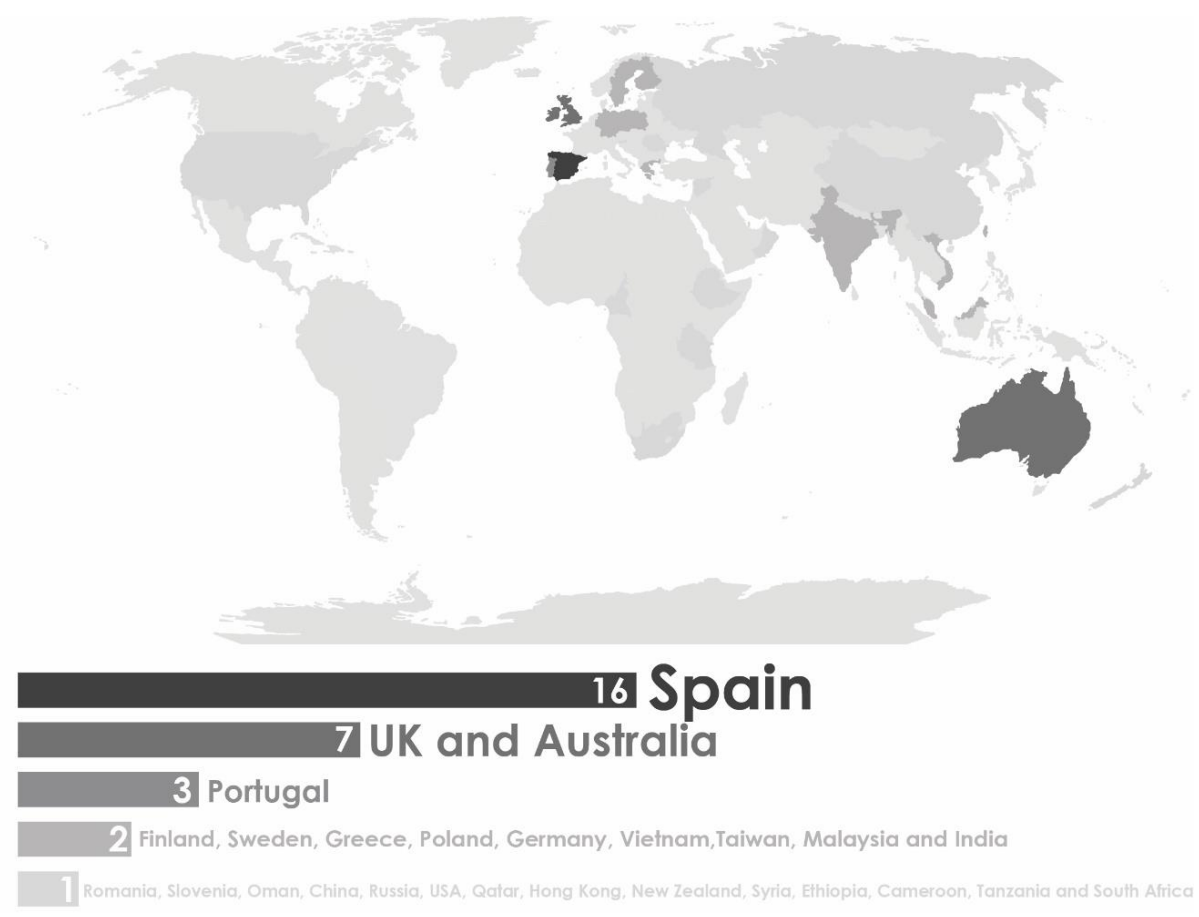

Figure 4. Worldwide distribution of the studies.

Out of the 16 papers identified in the previous section related to matching university graduates' competences with employers' needs, 12 originate in Europe (six from Spain (10W, 23W, 53W, 56W, 60W, $11 S)$, two from Finland $(48 \mathrm{~W}, 5 \mathrm{~S})$, one from Greece $(7 \mathrm{~W})$, one from Poland $(49 \mathrm{~W})$, one from Portugal $(41 \mathrm{~W})$, and one from Slovenia $(55 \mathrm{~W}))$. Three of the remaining articles present studies carried out in Oceania (Australia (3W, 28W), and New Zealand (1S)) and one from Asia (Russia (5W)). Relatively few of the articles conducted in Asian countries relate to this issue, and none of the African or American 
studies is found in this category. Also, notably, none originates in the UK, despite it being one of the best-represented countries in the sample.

Out of the eight papers related to undergraduates' self-perceived employability, six are based in studies conducted in Europe (four of which in the UK (15W, 33W, 44W, 59W), and two in Spain $(23 \mathrm{~W}, 36 \mathrm{~W}))$, two in studies conducted in Oceania (Australia $(33 \mathrm{~W}, 54 \mathrm{~W})$ ), and one in Asia (Taiwan (4S)). The UK stands out among papers included in this category.

The five studies concerned with the development and validation of an instrument are also predominantly carried out in European countries (Spain (3S, 53W), the UK (9W), Greece, 32W)). One such study has taken place in Oceania (Australia $(27 \mathrm{~W})$ ).

Among the 14 papers originated in Asia $(5 \mathrm{~W}, 4 \mathrm{~S}, 8 \mathrm{~W}, 11 \mathrm{~W}, 13 \mathrm{~W}, 19 \mathrm{~W}, 24 \mathrm{~W}, 25 \mathrm{~W}, 39 \mathrm{~W}, 42 \mathrm{~W}$, $43 \mathrm{~W}, 45 \mathrm{~W}, 8 \mathrm{~S}, 13 \mathrm{~S}$ ), there is a multitude of specific foci of analysis. However, an interest in language skills-namely in English as a foreign language-was present in three of the papers originated from Asia $(8 \mathrm{~W}, 39 \mathrm{~W}, 8 \mathrm{~S})$, outlining a possible specific concern for academics in this region of the globe.

All papers presenting studies carried out in Africa $(7 S, 20 \mathrm{~W}, 22 \mathrm{~W}, 30 \mathrm{~W})$ are concerned with enhancing higher education graduates' employability, focusing on the role of higher education institutions, despite the fact that they analyse different issues.

In summary, in Section 3.3, we analysed the worldwide distribution of the studies. Europe and Asia stood out as the continents producing more research on the topic. In particular, Spain was by far the most prolific country, followed by the UK, Australia, and Portugal. There were notably few papers originated in the Americas (none from South America and only one from North America) and from Africa. Specific concerns that are apparent from the analysis include a concern with the development of language skills, namely English as a foreign language, in Asian countries, and a concern with the role of HEIs in fostering graduate employability in African studies.

\section{Discussion}

This paper provides insight into the competence-based dimension of employability around the world. The paper starts by identifying what the main research issues related to competence development and graduate employability are. The results reveal that papers are mostly aimed at determining which competences act as a stimulus for employment and which ones discourage recruitment, or which ones should be regarded as more important to meet the demands of the labour market by graduates and universities. In this regard, there are two main ideas that might be interesting to explore, considering the results previously presented.

The first idea focuses on the two countries which can be identified as having a particular concern on this matter, Spain and Australia, which is also consistent with the results presented in Figure 4. One of the research questions of this paper referred to international concern about this topic. Thus, according to our findings, in Spain, most of the studies carried out take into account specific situations identified by the graduates $(62 \mathrm{~W})$, namely the underemployment situation of young people with university qualifications which is particularly worrying $(23 \mathrm{~W})$. Australian higher education institutions have been under tremendous pressure under the influence of international initiatives such as the Bologna process to develop a set of graduate attributes that serve as learning outcomes of a degree program. The context of the Fourth Industrial Revolution raises this concern and fosters a reflection upon curriculum design and development (3W).

It is also important to highlight other results worldwide. In Asia there is a concern with language skills, namely in English as a foreign language, outlining a possible specific interest for academics in this region of the globe. We did not encounter other relevant specificities. There is still scarce research on the topic that could allow the identification of contextual influences that hinder or enable the development of competences. No specific study has focussed on contextual influences specifically, and no paper is primarily devoted to this topic. Results show that research on this particular dimension is in an initial phase. Despite there being papers that contextualize the study, little has been published specifically on this topic. Therefore, we strongly suggest that research should continue to focus on 
contextual factors that may be key in competence development and employability. Presently, education systems around the world are vigorously working to manage the coronavirus (COVID-19) pandemic. During the recent pandemic, about 102 countries around the world have shut down all schools in an effort to halt the spread of the virus, affecting almost 900 million children and youth [27]. Considering advantaged families are more likely to have parents with higher levels of digital skills who can support the learning of children who cannot attend school, students from less well-off families are less likely to have this support, which means they risk falling further behind [27]. Therefore, future research on this issue should pay particular attention to address differences in competence development regarding the most vulnerable social groups, that are academically disadvantaged [28].

The second idea focuses on the two categories of competences identified in the results, namely technical competences also known as core competences [13] or subject-specific competences [29] which are related to professional practice and strongly linked to the areas of knowledge [30]; and transversal competences which are also known as soft skills [31]. According to our findings, the term soft skills is widely used (13W, 12S, 13S, 31W, 27W, 40W, 32W, 42W). Nevertheless, in the literature, it is also possible to identify other terms, such as transferable competences [13], generic skills [32], or employability competences [33]. Despite the diversity of terminology, these competences refer to those that are beyond technical subjects but are also related to professional practice [30]. For instance, based on our findings, it is possible to highlight a set of transversal competences that can be associated with graduate employability, namely,

1. Communication (1W) (3S) (5S) (8S) (11S) (24W) (26W) (30W) (32W) (39W) (40W) (42W) (43W) $(50 \mathrm{~W})(58 \mathrm{~W})$ with a particularly focus on foreign languages which is consistent with other studies (e.g., Lima et al. [34]);

2. Teamwork (1S) (23W) (24W) (26W) (30W) (37W) (42W) (43W) (46W) (52W) (54W) considering their relevance for the professional practice in all areas of knowledge (engineering, medicine, psychology, management, etc.) [35];

3. Digital competences $(2 \mathrm{~S})(11 \mathrm{~S})(40 \mathrm{~W})(46 \mathrm{~W})(56 \mathrm{~W})(60 \mathrm{~W})$ which are gaining particular relevance in the context of the Fourth Industrial Revolution [3].

The question that might arise from this discussion is: how can these competences be developed and assessed? Based on our review of the research that presents some curriculum adaptations, we found these to be very scarce. Wieman [36] reflects that universities face the challenge of teaching the ever-growing and increasingly diverse student body more complex thinking and problem-solving skills than were ever needed in the past. In this review, it is also noteworthy that there is a lack of research understanding of how these competences can be fostered and developed. More in-depth research is needed to understand how we can effectively evaluate this set of competences and how they can be developed.

However, the results described in our second research question already point out some initiatives about how higher education institutions can enhance the development of competences for graduates' employability. The main challenge identified in most of the studies is how to embed the competences in the curriculum design. It is clear that the competences that foster employability include technical and transversal competences. The challenge is to combine both types in the curriculum approach, to provide opportunities and conditions for students to develop them during their initial training [27-31]. According to our findings, this a global challenge: identified at least in Australia (4W), Africa (22W, $7 S)$, Europe $(35 \mathrm{~W}, 61 \mathrm{~W}, 11 \mathrm{~S}, 12 \mathrm{~S})$, and Asia $(39 \mathrm{~W}, 45 \mathrm{~W}, 8 \mathrm{~S})$. This opens an opportunity for future research, also identified by Römgens, Scoupe, and Beausaert [11], who suggest further studies to address the differences between different cultures, countries, and regions regarding curriculum design and development using a competence-based approach to employability.

A competence-based approach to employability in curriculum design and development in higher education is now more than a challenge; it is an urgent need. Considering the recent coronavirus (COVID-19) outbreak, we are at the cusp of a major recession. This crisis has already brought 
considerable change to our educational systems and significant economic disruption. The OECD Interim Economic Assessment (2020) stresses coronavirus containment efforts have involved quarantines and widespread restrictions on labour mobility and travel. The impacts of such constraints are significant, including the direct disruption to global supply chains, weaker final demand for imported goods and services, and broader regional declines in international tourism and business travel. Therefore, growth prospects are very uncertain, and currently, there are no accurate assumptions of the future concerning economy and employment. The relevance of this paper is thus further heightened by the present global context. Competence development approaches, mostly those which focus on the development of transversal competences, are even more crucial when economies are facing recession and the need for a rapid adaptation requiring flexibility and problem solving-although competence development can by no means be thought of as a panacea for such severe conditions, it may nonetheless make a difference to individuals' pathways when navigating these dire circumstances and trying to increase their odds in building successful careers. The current economy will demand skills that displace traditional ones. Vincent-Lancrin et al. [37], in their 2019 paper, identify a mix of skills that societies, higher education institutions and policymakers can contribute to foster. They highlight the relevance of higher education systems and institutions facing the challenge of equipping students with the skills required. Also, the debate about automation and the future of work has brought this issue to the heart of the matter (e.g., OECD Employment Outlook, 2012 [1]). In industry, human resources departments are working towards identifying skills that can be more difficult to automate [2]. Employee skill utilization can be seen as a driver of employees' outcomes and the sustainability of 'best practice' arguments across all skill levels, even in the face of recession. Therefore, nowadays, common policies are being developed to foster higher-order skills such as creativity and critical thinking as well as socio-emotional skills (see Vicent-Lancrin et al., 2019 [37]). For instance, in 2016, chief executive officers and chief human resource officers of multinational and large domestic companies answered the World Economic Forum's 'Future of Job' survey identifying critical skills for the labour market [38]. In 2018, the study reported similar results [39]. Remarkably, the 2018 paper underlines the importance of human skills such as creativity, originality and initiative, critical thinking, persuasion and negotiation [39].

With this in mind, it is crucial to understand how pedagogical practices can support the dimensions of employability [11]. Only a few studies analysed in this review highlight the importance of work-based experiences in higher education, in order to prepare graduates for the real context of their professional practice (examples: projects and case studies developed in authentic settings, technical visits, internships). These experiences enhance contact with real contexts, providing opportunities for students to develop not only technical competences, but also transversal ones. For instance, to collect data for students to solve a case or to develop a project, students need to interact with different professionals in the company. This context implies a highly sophisticated level of communication, in which the students also need to mobilize technical skills to gather the data they need.

The approach is also called pedagogies for employability [40], in which curriculum design and development includes an innovative approach across departments and courses, including six dimensions: learning and teaching practice, alternative methods of assessment, work-based and work-related learning; staff engagement; pedagogy competences; and strategy. According to the authors, a major barrier in this approach 'is the culture that exists in many institutions of rewarding research activity rather than teaching and other scholarly activity ... This has an impact on attempts to raise the quality of teaching provision and to refocus aspects of provision on employability and the innovative (and time-consuming) teaching approaches that this implies' (p. 41).

The post-Covid19 scenario, with restrictions to the kinds of pedagogical interactions in which such pedagogies can be fostered, also makes this a more pressing matter, and one which faces novel opportunities and threats. Are schools prepared to participate in the most rapid digital transformation ever [38]? Not for a minute have teachers refused to enter a very new educational setting and a vast majority have a strong and a positive attitude towards change and innovation. Also, most teachers feel control over their practice and seem more open to innovation than our industrial school organization 
suggests. This study also shows that a vast majority of teachers joined the profession to make a difference to society and children. The crisis has proved to be a major opportunity to extend forms of professional collaboration, team teaching and the adoption of effective teaching practices and professional collaboration [38]. Our results show scarce research worldwide concerning this topic, and, as is patent in the results section, research does not show evaluations of intervention programs. We still do not have effective tools that help undertake the challenges of integrating technical or professional skills and human skills in the academic system. Wieman 2019 [36] also remarks that the adoption of specific policies and procedures by education systems is needed, involving the effective training of teachers, similar to good training in any area of expertise, practising the relevant thinking and actions in authentic contexts, along with feedback to guide improvement. As in academic disciplines, the most essential part of training in teaching is to practice the relevant decision-making processes, recognizing what information is most important to guide those decisions and using it accordingly. This will require training that is both more extensive and more targeted than most existing university teacher training programs.

As a final remark, it is important to acknowledge the fact that graduate employability and competence development around the world depend on a strong sense of innovation and collaboration in higher education practices.

\section{Conclusions}

This paper aims to develop a systematic review on graduate employability and competence development. It also considers how higher education institutions are regarding the promotion and development of competences for employability. The paper highlights the relevance of competence development and graduate employability in two databases chosen for their impact and quality assurance. Taking into account that different countries and higher education systems attribute differing levels of importance to publishing in these specific databases, this choice may have led to the underrepresentation of some areas of the globe. We suggest that future research may include other databases to find more sources of heterogeneity. Results identify Europe as the continent where most of the research on these subjects has originated, over the past decade, with mainly quantitative studies.

The debate about gaps between the employability competences developed in higher education and employers' needs, and specificities associated with competence development represent the majority of the studies in the corpus of analysis. Our results suggest that higher education institutions are concerned with how to enhance the development of competences for graduate employability. Graduate employability and competence development around the world call for strong sense of innovation and collaboration practices implemented in higher education. However, our results show there is a long way to go towards the implementation of sustainable policies on this topic by Higher Education Institutions. We have not found any papers debating the relevance of developing governmental and institutional policies than promote a broad implementation of measures directed at promoting competences for employability in higher education. While employers are bringing this issue to government agendas, the development of competences remains a field controlled by academics, often based on individual decision-making, rather than an integrative institutional approach being described in the papers. Higher education institutions should be talent engines that foster innovation and competence development, without being hostages of organizations, however, a fruitful collaboration may be co-constructed and fostered. In addition, despite several studies approaching this concern, there is still insufficient understanding of how these competences can be fostered and developed. More in-depth research is needed in order to understand how to effectively evaluate this set of competences and how they can be developed.

The development of competences in higher education is strongly related to Sustainable Development Goals (SDG) 4 (Quality Education) and SDG 8 (Decent Work and Economic Growth). Governments, multilateral agencies, and higher education institutions must work together by targeting publicly funded research and building partnerships across sectors [41,42]. 
There is a need for intentional and evidence-based policy development and implementation at the multinational, national, and institutional levels. Despite the relevance of individual faculty members' initiative in inserting the issue on their courses or making efforts towards addressing the topic on their curricular units, recommendations about formalization and recognition of the importance of competence development for employability in the strategic development plan of each higher education institution should be made. Governmental and institutional policies must be developed; higher education institutions must include this issue on their agenda in order to foster and formalize the relevance of bridging the gap between the perceptions of higher education institutions and employers on competence development.

Author Contributions: Conceptualization, M.A.; Data curation, M.A., S.F., and D.M.; Investigation, M.A., S.F., D.M., F.S. and A.T.F.-O.; Methodology, A.T.F.-O.; Validation, F.S. and A.T.F.-O.; Writing—original draft, M.A., S.F., D.M., F.S. and A.T.F.-O.; Writing-review and editing, M.A. and F.S. All authors have read and agreed to the published version of the manuscript.

Funding: This research received no external funding.

Acknowledgments: The authors acknowledge Luís Borges for the design work.

Conflicts of Interest: The authors declare no conflict of interest.

\section{Appendix A}

Table A1. Codification of Papers included in the Systematic Review

\begin{tabular}{|c|c|c|c|c|c|}
\hline Code & Year & Authors & Journal Name & Title & Reference \\
\hline $1 \mathrm{~S}$ & 2019 & $\begin{array}{l}\text { Fraser, C., Duignan, G., } \\
\text { Stewart, D., and } \\
\text { Rodrigues, A., }\end{array}$ & $\begin{array}{l}\text { Journal of Teaching } \\
\text { and Learning for } \\
\text { Graduate } \\
\text { Employability }\end{array}$ & $\begin{array}{l}\text { Overt and covert: Strategies } \\
\text { for building employability } \\
\text { skills of vocational } \\
\text { education graduates }\end{array}$ & [43] \\
\hline $2 \mathrm{~S}$ & 2019 & Ashenafi Abate Woya & $\begin{array}{l}\text { Education Research } \\
\text { International }\end{array}$ & $\begin{array}{l}\text { Employability among } \\
\text { Statistics Graduates: } \\
\text { Graduates' Attributes, } \\
\text { Competence, and Quality } \\
\text { of Education }\end{array}$ & [44] \\
\hline $3 S$ & 2016 & $\begin{array}{l}\text { Verano-Tacoronte, D., } \\
\text { González-Betancor, S., } \\
\text { Bolívar-Cruz, A., } \\
\text { Fernández-Monroy, M., } \\
\text { and Galván-Sánchez, I. }\end{array}$ & $\begin{array}{l}\text { Revista Brasileira de } \\
\text { Educação }\end{array}$ & $\begin{array}{l}\text { Valoración de la competencia } \\
\text { de comunicación oral de } \\
\text { estudiantes universitarios a } \\
\text { través de una rúbrica fiable } \\
\text { y válida }\end{array}$ & [45] \\
\hline $4 \mathrm{~S}$ & 2015 & Hsuan-Fu Ho & $\begin{array}{c}\text { International } \\
\text { Education Studies }\end{array}$ & $\begin{array}{l}\text { Matching University } \\
\text { Graduates' Competences with } \\
\text { Employers' Needs in Taiwan }\end{array}$ & [46] \\
\hline $5 S$ & 2014 & $\begin{array}{l}\text { Backa, L., and } \\
\text { Wihersaari, M. }\end{array}$ & Engineering Education & $\begin{array}{c}\text { Future Engineering Education: } \\
\text { What Competences are Energy } \\
\text { Companies Looking for when } \\
\text { Recruiting Graduates with a } \\
\text { Master of Science } \\
\text { (Technology) Degree? }\end{array}$ & [47] \\
\hline $6 \mathrm{~S}$ & 2014 & Jackson, D. & $\begin{array}{c}\text { Journal of Education } \\
\text { and Work }\end{array}$ & $\begin{array}{l}\text { Testing a model of } \\
\text { undergraduate competence in } \\
\text { employability skills and its } \\
\text { implications for stakeholders }\end{array}$ & [48] \\
\hline $7 \mathrm{~S}$ & 2014 & $\begin{array}{l}\text { Moolman, H.J., and } \\
\text { Wilkinson, A. }\end{array}$ & Tourism & $\begin{array}{l}\text { Essential generic attributes for } \\
\text { enhancing the employability } \\
\text { of hospitality } \\
\text { management graduates }\end{array}$ & [49] \\
\hline $8 \mathrm{~S}$ & 2014 & $\begin{array}{l}\text { Al-Mahrooqi, R., and } \\
\text { Tuzlukova, V. }\end{array}$ & $\begin{array}{l}\text { Social Sciences \& } \\
\text { Humanities }\end{array}$ & $\begin{array}{c}\text { English Communication Skills } \\
\text { and Employability in the } \\
\text { Arabian Gulf: The Case } \\
\text { of Oman }\end{array}$ & [50] \\
\hline
\end{tabular}


Table A1. Cont.

\begin{tabular}{|c|c|c|c|c|c|}
\hline Code & Year & Authors & Journal Name & Title & Reference \\
\hline $9 \mathrm{~S}$ & 2013 & $\begin{array}{l}\text { Córcoles, Y.R., and } \\
\text { Lizano, M.M. }\end{array}$ & $\begin{array}{l}\text { Revista de Estudios } \\
\text { Regionales }\end{array}$ & $\begin{array}{l}\text { Characterization of Spanish } \\
\text { Universities behavior in relation } \\
\text { to the disclosure of intangibles }\end{array}$ & REMOVED \\
\hline $10 \mathrm{~S}$ & 2012 & $\begin{array}{c}\text { Haley, W.E., Ferraro, } \\
\text { K.F., and Montgomery, } \\
\text { R.J.V. }\end{array}$ & $\begin{array}{c}\text { Gerontology and } \\
\text { Geriatrics Education } \\
\# 32\end{array}$ & $\begin{array}{l}\text { Is Gerontology Ready for } \\
\text { Accreditation? }\end{array}$ & REMOVED \\
\hline $11 \mathrm{~S}$ & 2011 & $\begin{array}{l}\text { Del-Arco Bravo, I., and } \\
\text { Rodríguez, P.E. }\end{array}$ & Bordon \#33 & $\begin{array}{l}\text { Evaluation of instrumental skills } \\
\text { of university graduates: A } \\
\text { comparative study } \\
\text { [Article@Valoración de las } \\
\text { competencias instrumentales de } \\
\text { los titulados universitarios: } \\
\text { estudio comparativo] }\end{array}$ & [51] \\
\hline $12 \mathrm{~S}$ & 2010 & Nilsson, S. & $\begin{array}{l}\text { Education and } \\
\text { Training \#34 }\end{array}$ & $\begin{array}{l}\text { Enhancing individual } \\
\text { employability: The perspective } \\
\text { of engineering graduates }\end{array}$ & [52] \\
\hline $13 S$ & 2010 & Gokuladas, V.K. & $\begin{array}{l}\text { International Journal } \\
\text { of Training and } \\
\text { Development \#35 }\end{array}$ & $\begin{array}{l}\text { Technical and non-technical } \\
\text { education and the employability } \\
\text { of engineering graduates: an } \\
\text { Indian case study }\end{array}$ & [53] \\
\hline $1 \mathrm{~W}$ & 2019 & $\begin{array}{l}\text { Abbas, J., and } \\
\text { Sagsan, M. }\end{array}$ & $\begin{array}{l}\text { Higher Education } \\
\text { Skills and Work-Based } \\
\text { Learning }\end{array}$ & $\begin{array}{l}\text { Identification of key } \\
\text { employability attributes and } \\
\text { evaluation of university } \\
\text { graduates' performance } \\
\text { Instrument development } \\
\text { and validation }\end{array}$ & REMOVED \\
\hline $2 \mathrm{~W}$ & 2019 & $\begin{array}{l}\text { Hora, M.T., Smolarek, } \\
\text { B.B., Martin, K.N., and } \\
\text { Scrivener, L. }\end{array}$ & $\begin{array}{l}\text { American Educational } \\
\text { Research Journal }\end{array}$ & $\begin{array}{l}\text { Exploring the Situated and } \\
\text { Cultural Aspects of } \\
\text { Communication in the } \\
\text { Professions: Implications for } \\
\text { Teaching, Student Employability, } \\
\text { and Equity in Higher Education }\end{array}$ & [54] \\
\hline $3 W$ & 2019 & $\begin{array}{l}\text { Prikshat, V., Montague, } \\
\text { A., Connell, J., and } \\
\text { Burgess, J. }\end{array}$ & $\begin{array}{l}\text { Higher Education } \\
\text { Skills and Work-Based } \\
\text { Learning }\end{array}$ & $\begin{array}{l}\text { Australian graduates' work } \\
\text { readiness - deficiencies, causes } \\
\text { and potential solutions }\end{array}$ & [55] \\
\hline $4 \mathrm{~W}$ & 2019 & Fraser, B. & $\begin{array}{l}\text { Journal of Hospitality } \\
\text { \& Tourism Education }\end{array}$ & $\begin{array}{l}\text { From Hospitality Classrooms to } \\
\text { Successful Careers: A Current } \\
\text { Appraisal of Australian } \\
\text { International } \\
\text { Hotel Requirements }\end{array}$ & [56] \\
\hline $5 \mathrm{~W}$ & 2019 & $\begin{array}{c}\text { Lichy, J., and Khvatova, } \\
\text { T. }\end{array}$ & $\begin{array}{c}\text { Journal of } \\
\text { Management } \\
\text { Development }\end{array}$ & $\begin{array}{l}\text { Rethinking solutions for } \\
\text { re-balancing the } \\
\text { education-job mismatch }\end{array}$ & [57] \\
\hline $6 \mathrm{~W}$ & 2019 & $\begin{array}{l}\text { Lopes, B., Silva, P., } \\
\text { Melo, A.I., Brito, E., } \\
\text { Dias, G.P., and } \\
\text { Costa, M. }\end{array}$ & Sustainability & $\begin{array}{l}\text { The 'Lunar Side' of the Story: } \\
\text { Exploring the Sustainability of } \\
\text { Curricular Internships in } \\
\text { Higher Education }\end{array}$ & [58] \\
\hline $7 \mathrm{~W}$ & 2019 & $\begin{array}{l}\text { Asonitou, S., and } \\
\text { Hassall, T. }\end{array}$ & $\begin{array}{l}\text { International Journal } \\
\text { of Management } \\
\text { Education }\end{array}$ & $\begin{array}{c}\text { Which skills and competences to } \\
\text { develop in accountants in a } \\
\text { country in crisis? }\end{array}$ & [59] \\
\hline $8 \mathrm{~W}$ & 2019 & $\begin{array}{l}\text { Tran, T.T.Q., Admiraal, } \\
\text { W., and Saab, N. }\end{array}$ & Intercultural Education & $\begin{array}{l}\text { Effects of critical incident tasks } \\
\text { on the intercultural competence } \\
\text { of English non-majors }\end{array}$ & [60] \\
\hline $9 \mathrm{~W}$ & 2019 & $\begin{array}{l}\text { Cronin, L., Allen, J., } \\
\text { Ellison, P., Marchant, } \\
\text { D., Levy, A., and } \\
\text { Harwood, C. }\end{array}$ & $\begin{array}{l}\text { Studies In Higher } \\
\text { Education }\end{array}$ & $\begin{array}{l}\text { Development and initial } \\
\text { validation of the life skills ability } \\
\text { scale for higher } \\
\text { education students }\end{array}$ & [61] \\
\hline $10 \mathrm{~W}$ & 2019 & $\begin{array}{l}\text { Pais-Montes, C., } \\
\text { Freire-Seoane, M.J., } \\
\text { and } \\
\text { Lopez-Bermudez, B. }\end{array}$ & $\begin{array}{l}\text { Industry and Higher } \\
\text { Education }\end{array}$ & $\begin{array}{c}\text { Employability traits for } \\
\text { engineers: A } \\
\text { competencies-based approach }\end{array}$ & [62] \\
\hline
\end{tabular}


Table A1. Cont.

\begin{tabular}{|c|c|c|c|c|c|}
\hline Code & Year & Authors & Journal Name & Title & Reference \\
\hline $11 \mathrm{~W}$ & 2019 & $\begin{array}{l}\text { Rasiah, R., Turner, J., } \\
\text { and Ho, Y.F. }\end{array}$ & $\begin{array}{l}\text { Contemporary } \\
\text { Economics }\end{array}$ & $\begin{array}{l}\text { The Impact of Emotional } \\
\text { Intelligence on Work } \\
\text { Performance: Perceptions and } \\
\text { Reflections from Academics in } \\
\text { Malaysian Higher Education } \\
\text { Obitat endiaest que }\end{array}$ & [63] \\
\hline $12 \mathrm{~W}$ & 2019 & $\begin{array}{l}\text { Iglesias-Sánchez, P.P., } \\
\text { Jambrino-Maldonado } \\
\text { C., and } \\
\text { Heras-Pedrosa, C. }\end{array}$ & Sustainability & $\begin{array}{l}\text { Training Entrepreneurial } \\
\text { Competences with Open } \\
\text { Innovation Paradigm in } \\
\text { Higher Education }\end{array}$ & [64] \\
\hline $13 \mathrm{~W}$ & 2019 & $\begin{array}{l}\text { Yao, C.W., and } \\
\text { Tuliao, M.D. }\end{array}$ & $\begin{array}{l}\text { Higher Education } \\
\text { Skills and Work-Based } \\
\text { Learning }\end{array}$ & $\begin{array}{l}\text { Soft skill development for } \\
\text { employability A case study of } \\
\text { stem graduate students at a } \\
\text { Vietnamese } \\
\text { transnational university }\end{array}$ & [65] \\
\hline $14 \mathrm{~W}$ & 2019 & $\begin{array}{l}\text { Cojocariu, M., } \\
\text { Cîrtiţă-Buzoianu, C., } \\
\text { and Mareș, G. }\end{array}$ & Postmodern Openings & $\begin{array}{l}\text { Opportunities and Difficulties } \\
\text { in Conducting Internships in } \\
\text { Higher Education from the } \\
\text { Employers' Perspective }\end{array}$ & [66] \\
\hline $15 \mathrm{~W}$ & 2019 & $\begin{array}{l}\text { Donald, W.E., Baruch, } \\
\text { Y., and Ashleigh, M. }\end{array}$ & $\begin{array}{l}\text { Studies in Higher } \\
\text { Education }\end{array}$ & $\begin{array}{l}\text { The undergraduate } \\
\text { self-perception of } \\
\text { employability: human capital, } \\
\text { careers advice, and }\end{array}$ & [67] \\
\hline $16 \mathrm{~W}$ & 2019 & $\begin{array}{l}\text { Ornellas, A., Falkner, } \\
\text { K., and Stalbrandt, E.E. }\end{array}$ & $\begin{array}{l}\text { Higher Education } \\
\text { Skills and Work-Based } \\
\text { Learning }\end{array}$ & $\begin{array}{l}\text { Enhancing graduates' } \\
\text { employability skills through } \\
\text { authentic learning approaches }\end{array}$ & [68] \\
\hline $17 \mathrm{~W}$ & 2019 & $\begin{array}{l}\text { Redomero, T., } \\
\text { Caggiano, V., } \\
\text { Poza-Lujan, J.L., and } \\
\text { Piccione, V.A. }\end{array}$ & $\begin{array}{l}\text { International Journal of } \\
\text { Engineering Education }\end{array}$ & $\begin{array}{l}\text { Fostering and Assessing Soft } \\
\text { Skills of Engineering Students }\end{array}$ & REMOVED \\
\hline $18 \mathrm{~W}$ & 2019 & $\begin{array}{l}\text { Perez-Escoda, N., } \\
\text { Silvente, V.B., and } \\
\text { Bossello, A.A. }\end{array}$ & $\begin{array}{l}\text { Bordon-Revista De } \\
\text { Pedagogia }\end{array}$ & $\begin{array}{l}\text { The development of } \\
\text { socio-emotional skills in } \\
\text { higher education: assessment } \\
\text { of a university graduate } \\
\text { program in Emotional } \\
\text { Education }\end{array}$ & REMOVED \\
\hline $19 \mathrm{~W}$ & 2019 & $\begin{array}{l}\text { Ali, A., and } \\
\text { Marwan, H. }\end{array}$ & $\begin{array}{l}\text { Journal of Technical } \\
\text { Education and } \\
\text { Training }\end{array}$ & $\begin{array}{l}\text { Exploring Career } \\
\text { Management Competencies in } \\
\text { Work Based Learning (WBL) } \\
\text { Implementation }\end{array}$ & [69] \\
\hline $20 \mathrm{~W}$ & 2019 & Ashenafi Abate Woya & $\begin{array}{l}\text { Education Research } \\
\text { International }\end{array}$ & $\begin{array}{c}\text { Employability among } \\
\text { Statistics Graduates: } \\
\text { Graduates' Attributes, } \\
\text { Competence, and Quality } \\
\text { of Education }\end{array}$ & [44] \\
\hline $21 \mathrm{~W}$ & 2018 & $\begin{array}{l}\text { Bolivar-Cruz, A., and } \\
\text { Verano-Tacoronte, D. }\end{array}$ & $\begin{array}{l}\text { Studies In } \\
\text { Educational Evaluation }\end{array}$ & $\begin{array}{l}\text { Self-assessment of the oral } \\
\text { presentation competence: } \\
\text { Effects of gender and student's } \\
\text { performance }\end{array}$ & [70] \\
\hline $22 \mathrm{~W}$ & 2018 & Eta, E.A. & $\begin{array}{c}\text { Higher } \\
\text { Education Policy }\end{array}$ & $\begin{array}{l}\text { Enhancing Graduate } \\
\text { Employability in } \\
\text { Cameroonian Universities } \\
\text { Through Professionalization } \\
\text { in the Context of the } \\
\text { 'Licence-Master-Doctorat' Reform }\end{array}$ & [71] \\
\hline $23 \mathrm{~W}$ & 2018 & $\begin{array}{l}\text { Pineda-Herrero, P., } \\
\text { Ciraso-Cali, A., and } \\
\text { Armijos-Yambay, M. }\end{array}$ & $\begin{array}{l}\text { Revista Espanola De } \\
\text { Pedagogia }\end{array}$ & $\begin{array}{l}\text { Employability and } \\
\text { competences of Pedagogy, } \\
\text { Psychology, and Educational } \\
\text { Psychology graduates: a } \\
\text { comparative study of } \\
\text { employers and graduates }\end{array}$ & [72] \\
\hline
\end{tabular}


Table A1. Cont.

\begin{tabular}{|c|c|c|c|c|c|}
\hline Code & Year & Authors & Journal Name & Title & Reference \\
\hline $24 \mathrm{~W}$ & 2018 & $\begin{array}{l}\text { Sehgal, N., and } \\
\text { Nasim, S. }\end{array}$ & $\begin{array}{l}\text { Higher Education } \\
\text { Skills and Work-Based } \\
\text { Learning }\end{array}$ & $\begin{array}{l}\text { Total Interpretive Structural } \\
\text { Modelling of predictors for } \\
\text { graduate employability for the } \\
\text { information technology sector }\end{array}$ & [73] \\
\hline $25 \mathrm{~W}$ & 2018 & $\begin{array}{l}\text { Chan, C.K.Y., and } \\
\text { Fong, E.T.Y. }\end{array}$ & $\begin{array}{l}\text { European Journal of } \\
\text { Engineering Education }\end{array}$ & $\begin{array}{l}\text { Disciplinary differences and } \\
\text { implications for the } \\
\text { development of generic skills: } \\
\text { a study of engineering and } \\
\text { business students' perceptions } \\
\text { of generic skills }\end{array}$ & [74] \\
\hline $26 \mathrm{~W}$ & 2018 & $\begin{array}{l}\text { Bautista-Mesa, R., } \\
\text { Sánchez, H.M., and } \\
\text { Sobrino, J.N.R. }\end{array}$ & Accounting Education & $\begin{array}{c}\text { Audit workplace simulations } \\
\text { as a methodology to increase } \\
\text { undergraduates' awareness } \\
\text { of competences }\end{array}$ & [75] \\
\hline $27 \mathrm{~W}$ & 2018 & $\begin{array}{l}\text { Sandri, O., } \\
\text { Holdsworth, S., and } \\
\text { Thomas, I. }\end{array}$ & $\begin{array}{c}\text { Environmental } \\
\text { Education Research }\end{array}$ & $\begin{array}{l}\text { Vignette question design for } \\
\text { the assessment of graduate } \\
\text { sustainability } \\
\text { learning outcomes }\end{array}$ & [76] \\
\hline $28 \mathrm{~W}$ & 2018 & $\begin{array}{c}\text { Sandri, O., } \\
\text { Holdsworth, S., and } \\
\text { Thomas, I. }\end{array}$ & $\begin{array}{l}\text { International Journal } \\
\text { of Sustainability in } \\
\text { Higher Education }\end{array}$ & $\begin{array}{c}\text { Assessing graduate } \\
\text { sustainability capability } \\
\text { post-degree completion Why } \\
\text { is it important and what are } \\
\text { the challenges? }\end{array}$ & [77] \\
\hline $29 \mathrm{~W}$ & 2017 & Moolman, H. & $\begin{array}{l}\text { Independent Journal of } \\
\text { Teaching and Learning }\end{array}$ & $\begin{array}{c}\text { A conceptual } \\
\text { competence-based framework } \\
\text { for enhancing the } \\
\text { employability of graduates }\end{array}$ & [78] \\
\hline $30 \mathrm{~W}$ & 2017 & Ishengoma, J.M. & $\begin{array}{l}\text { Tuning Journal for } \\
\text { Higher Education }\end{array}$ & $\begin{array}{c}\text { Incorporating the Tuning } \\
\text { Approach in Higher } \\
\text { Education curricular reforms } \\
\text { and course design in Tanzania } \\
\text { for enhancing graduates' } \\
\text { competencies: } \\
\text { stakeholders' views }\end{array}$ & [79] \\
\hline $31 \mathrm{~W}$ & 2017 & $\begin{array}{l}\text { Ordonez, J.L., Gazo, } \\
\text { Figuera P., and } \\
\text { Fonseca, M.T. }\end{array}$ & $\begin{array}{l}\text { Revista Espanola de } \\
\text { Orientacion y } \\
\text { Psicopedagogia }\end{array}$ & $\begin{array}{l}\text { Employability and Career } \\
\text { Management of Graduates } \\
\text { in Pedagogy }\end{array}$ & [80] \\
\hline $32 \mathrm{~W}$ & 2017 & $\begin{array}{l}\text { Tsitskari, E., Goudas, } \\
\text { M., Tsalouchou, E., and } \\
\text { Michalopoulou, M. }\end{array}$ & $\begin{array}{l}\text { Journal of Hospitality } \\
\text { Leisure Sport \& } \\
\text { Tourism Education }\end{array}$ & $\begin{array}{l}\text { Employers' expectations of the } \\
\text { employability skills needed in } \\
\text { the sport and } \\
\text { recreation environment }\end{array}$ & [81] \\
\hline $33 \mathrm{~W}$ & 2017 & $\begin{array}{l}\text { Jackson, D. and } \\
\text { Wilton, N. }\end{array}$ & $\begin{array}{l}\text { Higher Education } \\
\text { Research \& } \\
\text { Development }\end{array}$ & $\begin{array}{l}\text { Perceived employability } \\
\text { among undergraduates and } \\
\text { the importance of career } \\
\text { self-management, work } \\
\text { experience and } \\
\text { individual characteristics }\end{array}$ & [82] \\
\hline $34 \mathrm{~W}$ & 2017 & $\begin{array}{l}\text { Pinto, L.H., and } \\
\text { Ramalheira, D.C. }\end{array}$ & $\begin{array}{c}\text { Journal of Vocational } \\
\text { Behavior }\end{array}$ & $\begin{array}{l}\text { Perceived employability of } \\
\text { business graduates: The effect } \\
\text { of academic performance and } \\
\text { extracurricular activities }\end{array}$ & [83] \\
\hline $35 \mathrm{~W}$ & 2017 & de Cespedes, B.R. & $\begin{array}{l}\text { Interpreter and } \\
\text { Translator Trainer }\end{array}$ & $\begin{array}{l}\text { Addressing employability and } \\
\text { enterprise responsibilities in } \\
\text { the translation curriculum }\end{array}$ & [84] \\
\hline $36 \mathrm{~W}$ & 2017 & $\begin{array}{l}\text { Alvarez-Alvarez, S., } \\
\quad \text { and } \\
\text { Arnaiz-Uzquiza, V. }\end{array}$ & $\begin{array}{l}\text { Interpreter and } \\
\text { Translator Trainer }\end{array}$ & $\begin{array}{l}\text { Translation and interpreting } \\
\text { graduates under construction: } \\
\text { do Spanish translation and } \\
\text { interpreting studies curricula } \\
\text { answer the challenges } \\
\text { of employability }\end{array}$ & [85] \\
\hline
\end{tabular}


Table A1. Cont.

\begin{tabular}{|c|c|c|c|c|c|}
\hline Code & Year & Authors & Journal Name & Title & Reference \\
\hline $37 \mathrm{~W}$ & 2017 & $\begin{array}{l}\text { Schnell, B., and } \\
\text { Rodriguez, N. }\end{array}$ & $\begin{array}{l}\text { Interpreter and } \\
\text { Translator Trainer }\end{array}$ & $\begin{array}{l}\text { Ivory tower vs. workplace } \\
\text { reality Employability and the } \\
\text { T\&I curriculum - balancing } \\
\text { academic education and } \\
\text { vocational requirements: a } \\
\text { study from the } \\
\text { employers' perspective }\end{array}$ & [86] \\
\hline $38 \mathrm{~W}$ & 2017 & $\begin{array}{l}\text { Yoong, D., Don, Z.M. } \\
\text { and Foroutan, M. }\end{array}$ & $\begin{array}{c}\text { Journal of Education } \\
\text { and Work }\end{array}$ & $\begin{array}{l}\text { Prescribing roles in the } \\
\text { employability of } \\
\text { Malaysian graduates }\end{array}$ & REMOVED \\
\hline $39 \mathrm{~W}$ & 2017 & Yang, W.H. & $\begin{array}{l}\text { International Journal } \\
\text { of Bilingual Education } \\
\text { and Bilingualism }\end{array}$ & $\begin{array}{l}\text { Tuning university } \\
\text { undergraduates for high } \\
\text { mobility and employability } \\
\text { under the content and } \\
\text { language integrated } \\
\text { learning approach }\end{array}$ & [87] \\
\hline $40 \mathrm{~W}$ & 2017 & $\begin{array}{c}\text { Sutherland, K., and Ho, } \\
\text { S. }\end{array}$ & $\begin{array}{l}\text { Higher Education } \\
\text { Skills and Work-Based } \\
\text { Learning }\end{array}$ & $\begin{array}{c}\text { Undergraduate perceptions of } \\
\text { social media proficiency and } \\
\text { graduate employability A } \\
\text { pilot study }\end{array}$ & [88] \\
\hline $41 \mathrm{~W}$ & 2017 & $\begin{array}{l}\text { Figueiredo, H., Biscaia, } \\
\text { R., Rocha, V., and } \\
\text { Teixeira, P. }\end{array}$ & $\begin{array}{c}\text { Studies in } \\
\text { Higher Education }\end{array}$ & $\begin{array}{l}\text { Should we start worrying? } \\
\text { Mass higher education, skill } \\
\text { demand and the increasingly } \\
\text { complex landscape of young } \\
\text { graduates' employment }\end{array}$ & [89] \\
\hline $42 \mathrm{~W}$ & 2017 & $\begin{array}{l}\text { Ayoubi, R.M., Alzarif, } \\
\text { K., and Khalifa, B. }\end{array}$ & $\begin{array}{l}\text { Education and } \\
\text { Training }\end{array}$ & $\begin{array}{l}\text { The employability skills of } \\
\text { business graduates in Syria Do } \\
\text { policymakers and employers } \\
\text { speak the same language? }\end{array}$ & [90] \\
\hline $43 \mathrm{~W}$ & 2017 & $\begin{array}{c}\text { Osmani, M., } \\
\text { Weerakkody, V., and } \\
\text { Hindi, N. }\end{array}$ & $\begin{array}{l}\text { Journal of Education } \\
\text { for Business }\end{array}$ & $\begin{array}{l}\text { Graduate attributes in higher } \\
\text { education: Examining } \\
\text { academics' perception in the } \\
\text { Middle East }\end{array}$ & [91] \\
\hline $44 \mathrm{~W}$ & 2017 & O'Leary, S. & $\begin{array}{l}\text { Journal of Education } \\
\text { and Work }\end{array}$ & $\begin{array}{l}\text { Graduates' experiences of, } \\
\text { and attitudes towards, the } \\
\text { inclusion of } \\
\text { employability-related support } \\
\text { in undergraduate degree } \\
\text { programmes; trends and } \\
\text { variations by subject discipline } \\
\text { and gender }\end{array}$ & [92] \\
\hline $45 \mathrm{~W}$ & 2016 & $\begin{array}{l}\text { Yang, H.J., Cheung, C., } \\
\text { and Song, H.Y. }\end{array}$ & $\begin{array}{l}\text { Journal of Hospitality } \\
\text { Leisure Sport \& } \\
\text { Tourism Education }\end{array}$ & $\begin{array}{l}\text { Enhancing the learning and } \\
\text { employability of hospitality } \\
\text { graduates in China }\end{array}$ & [93] \\
\hline $46 \mathrm{~W}$ & 2016 & $\begin{array}{l}\text { Pineda-Herrero, P., } \\
\text { Agud-Morell, I., and } \\
\text { Ciraso-Cali, A. }\end{array}$ & Revista de Educacion & $\begin{array}{l}\text { Factores que intervienen en la } \\
\text { inserción laboral de los } \\
\text { titulados en Educación en } \\
\text { tiempos de crisis: un estudio } \\
\text { sobre Cataluña }\end{array}$ & [94] \\
\hline $47 \mathrm{~W}$ & 2016 & Pirog, D. & $\begin{array}{l}\text { Studies In Higher } \\
\text { Education }\end{array}$ & $\begin{array}{l}\text { The impact of degree } \\
\text { programme educational } \\
\text { capital on the transition of } \\
\text { graduates to the labour market }\end{array}$ & [95] \\
\hline $48 \mathrm{~W}$ & 2016 & $\begin{array}{l}\text { Xia, B.S., and } \\
\text { Liitainen, E. }\end{array}$ & $\begin{array}{l}\text { International Journal } \\
\text { of Adult Vocational } \\
\text { Education and } \\
\text { Technology }\end{array}$ & $\begin{array}{l}\text { Implications of Higher } \\
\text { Education on Earnings: An } \\
\text { Empirical Analysis of Skills } \\
\text { and Competence }\end{array}$ & [96] \\
\hline
\end{tabular}


Table A1. Cont.

\begin{tabular}{|c|c|c|c|c|c|}
\hline Code & Year & Authors & Journal Name & Title & Reference \\
\hline $49 \mathrm{~W}$ & 2016 & Pirog, D. & Geographia Polonica & $\begin{array}{l}\text { The Role of Competences for } \\
\text { Geography Higher Education } \\
\text { in } \\
\text { University-To-Work Transition }\end{array}$ & [97] \\
\hline $50 \mathrm{~W}$ & 2016 & Kaburise, P. & $\begin{array}{l}\text { International Journal } \\
\text { of African } \\
\text { Renaissance Studies }\end{array}$ & $\begin{array}{c}\text { Improving soft skills and } \\
\text { communication in response to } \\
\text { youth unemployment }\end{array}$ & [98] \\
\hline $51 W$ & 2016 & Feldmann, L. & $\begin{array}{l}\text { Higher Education } \\
\text { Skills and } \\
\text { Work-Based Learning }\end{array}$ & $\begin{array}{l}\text { Considerations in the design } \\
\text { of WBL settings to enhance } \\
\text { students' employability A } \\
\text { synthesis of individual and } \\
\text { contextual perspectives }\end{array}$ & [99] \\
\hline $52 \mathrm{~W}$ & 2016 & $\begin{array}{c}\text { Perello-Marin, M.R., } \\
\text { Vidal-Carreras, P.I., } \\
\text { and; Marin-Garcia, J.A. }\end{array}$ & $\begin{array}{l}\text { International Journal of } \\
\text { Engineering Education }\end{array}$ & $\begin{array}{l}\text { What Do Undergraduates } \\
\text { Perceive About Teamwork? }\end{array}$ & [100] \\
\hline $53 \mathrm{~W}$ & 2016 & $\begin{array}{l}\text { Rodríguez, M.J.F., } \\
\text { Vicente, J.L.P., and } \\
\text { Siles, G.G. }\end{array}$ & Educación XX1 & $\begin{array}{l}\text { Una experiencia en la } \\
\text { vinculación } \\
\text { universidad-empresa: El } \\
\text { Proyecto Cogempleo De La }\end{array}$ & [101] \\
\hline $54 \mathrm{~W}$ & 2015 & $\begin{array}{l}\text { Cavanagh, J., Burston, } \\
\text { M., Southcombe, A., } \\
\text { and Bartram, T. }\end{array}$ & $\begin{array}{l}\text { International Journal } \\
\text { of Management } \\
\text { Education }\end{array}$ & $\begin{array}{l}\text { Contributing to a } \\
\text { graduate-centred } \\
\text { understanding of work } \\
\text { readiness: An exploratory } \\
\text { study of Australian } \\
\text { undergraduate students' } \\
\text { perceptions of their } \\
\text { employability }\end{array}$ & [102] \\
\hline $55 \mathrm{~W}$ & 2015 & $\begin{array}{l}\text { Donik1, B., Pajnkihar1, } \\
\text { M., and Bernik, M. }\end{array}$ & Organizacija & $\begin{array}{l}\text { Employability of Nursing } \\
\text { Care Graduates }\end{array}$ & [103] \\
\hline $56 \mathrm{~W}$ & 2015 & $\begin{array}{l}\text { Torres-Coronas, T., and } \\
\text { Vidal-Blasco, M.A. }\end{array}$ & Revista De Educacion & $\begin{array}{l}\text { Students and employers } \\
\text { perception about the } \\
\text { development of digital skills } \\
\text { in Higher Education }\end{array}$ & [104] \\
\hline $57 \mathrm{~W}$ & 2015 & $\begin{array}{l}\text { Fletcher-Brown, J., } \\
\text { Knibbs, K., and } \\
\text { Middleton, K. }\end{array}$ & $\begin{array}{l}\text { Higher Education } \\
\text { Skills and } \\
\text { Work-Based Learning }\end{array}$ & $\begin{array}{c}\text { Developing "employagility": } \\
\text { the 3Es case for } \\
\text { live-client learning }\end{array}$ & [105] \\
\hline $58 \mathrm{~W}$ & 2015 & $\begin{array}{c}\text { Pujol-Jover1, M., } \\
\text { Riera-Prunera, C., and } \\
\text { Abio, G. }\end{array}$ & Intangible Capital & $\begin{array}{l}\text { Competences acquisition of } \\
\text { university students: Do they } \\
\text { match job market's needs? }\end{array}$ & [106] \\
\hline $59 \mathrm{~W}$ & 2013 & Tymon, A. & $\begin{array}{l}\text { Studies in Higher } \\
\text { Education }\end{array}$ & $\begin{array}{c}\text { The student perspective } \\
\text { on employability }\end{array}$ & [107] \\
\hline $60 \mathrm{~W}$ & 2013 & $\begin{array}{l}\text { Martin-Del-Peso, M., } \\
\text { Gomez, A.B.R., and } \\
\text { March, J.H. }\end{array}$ & Revista de Educacion & $\begin{array}{l}\text { Mismatches between Higher } \\
\text { Education and the Labour } \\
\text { Market in Engineering } \\
\text { Sciences: The Employers' } \\
\text { Point of View in the Region } \\
\text { of Madrid }\end{array}$ & [108] \\
\hline $61 W$ & 2010 & $\begin{array}{l}\text { Hennemann, S., and } \\
\text { Liefner, I. }\end{array}$ & $\begin{array}{l}\text { Journal of Geography } \\
\text { in Higher Education }\end{array}$ & $\begin{array}{l}\text { Employability of German } \\
\text { Geography Graduates: The } \\
\text { Mismatch between } \\
\text { Knowledge Acquired and } \\
\text { Competences Required }\end{array}$ & [109] \\
\hline $62 W$ & 2010 & $\begin{array}{l}\text { Espinar, S.R., Nebot, } \\
\text { A.P., Arjona, L.B., and } \\
\text { Castineira, S.S. }\end{array}$ & Revista de Educacion & $\begin{array}{l}\text { Graduate employability in } \\
\text { Catalonia. From diagnosis } \\
\text { to action }\end{array}$ & [110] \\
\hline
\end{tabular}

$\mathrm{S}=$ Scopus $; \mathrm{W}=$ Web of Science. 


\section{References}

1. What Makes Labour Markets Resilient During Recessions? In OECD Employment Outlook 2012; OECD Publishing: Paris, France, 2012; pp. 53-107.

2. Okay-Somerville, B.; Scholarios, D. A multilevel examination of skills-oriented human resource management and perceived skill utilization during recession: Implications for the well-being of all workers. Hum. Resour. Manag. 2019, 58, 139-154. [CrossRef]

3. Schwab, K. Welcome to the Fourth Industrial Revolution. Rotman Manag. 2016, 25, 19-24.

4. Knight, P.; Yorke, M. Learning, Curriculum and Employability in Higher Education; Psychology Press: Hove, UK, 2003; ISBN 020346527X.

5. Small, L.; Shacklock, K.; Marchant, T. Employability: A contemporary review for higher education stakeholders. J. Vocat. Educ. Train. 2018, 70, 148-166. [CrossRef]

6. Artess, J.; Hooley, T.; Mellors-bourne, R. Employability: A Review of the Literature 2012 to 2016; A Report for the Higher Education Academy; Higher Education Academy (HEA): Heslington, UK, 2016.

7. Billet, S. Integrating Practice-Based Experiences into Higher Education; Springer: Dordrecht, The Netherlands, 2015.

8. Cranmer, S. Enhancing graduate employability: Best intentions and mixed outcomes. Stud. High. Educ. 2006, 31, 169-184. [CrossRef]

9. Gazier, B. Employability-The complexity of a Policy Notion. In Employability: From Theory to Practice; Routledge: New York, NY, USA, 2017; ISBN 9781351312004.

10. Peeters, E.; Nelissen, J.; De Cuyper, N.; Forrier, A.; Verbruggen, M.; De Witte, H. Employability Capital: A Conceptual Framework Tested through Expert Analysis. J. Career Dev. 2019, 46, 79-93. [CrossRef]

11. Römgens, I.; Scoupe, R.; Beausaert, S. Unraveling the concept of employability, bringing together research on employability in higher education and the workplace. Stud. High. Educ. 2019. [CrossRef]

12. Harvey, L. Transitions from Higher Education to Work: A Briefing Paper Prepared by Lee Harvey (Centre for Research and Evaluation, Sheffield Hallam University), with Advice from ESECT and LTSN Generic Centre Colleagues; LTSN Generic Centre: York, UK, 2003.

13. Yorke, M. Employability in Higher Education: What It Is, What It Is Not; Learning \& Employability Series; Higher Education Academy (HEA): Heslington, UK, 2006.

14. Hoffmann, T. The meanings of competency. J. Eur. Ind. Train. 1999, 23, 275-286. [CrossRef]

15. Ashworth, P.D.; Saxton, J. On 'Competence'. J. Furth. High. Educ. 1990, 14, 3-25. [CrossRef]

16. Westera, W. Competences in education: A confusion of tongues. J. Curric. Stud. 2001, 33, 75-88. [CrossRef]

17. Le Boterf, G. De la compétence à la navigation professionnelle; Les Éditions d' Organisation: Paris, France, 1997.

18. Le Boterf, G. Construir as Competências Individuais e Coletivas. Resposta a 80 Questões; Edições ASA: Porto, Portugal, 2005.

19. Zarifian, P. Objectif Compétence. Pour une Nouvelle Logique; Liaisons: Rueil-Mailmaison, France, 1999.

20. Stoof, A.; Martens, R.L.; Van Merriënboer, J.J.G.; Bastiaens, T.J. The Boundary Approach of Competence: A Constructivist Aid for Understanding and Using the Concept of Competence. Hum. Resour. Dev. Rev. 2002, 1, 345-365. [CrossRef]

21. Rychen, D.S.; Salganik, L.H. Key Competencies for a Successful Life and a Well-Functioning Society; OECD Definitions and Selection Competencies Final Report; Hogrefe \& Huber: Cambridge, MA, USA, 2003.

22. Wittorski, R. Professionalisation and the Development of Competences in Education and Training; Cohen-Scali, V., Ed.; Barbara Budrich Publisher: Opladen/Berlin, Germany; Toronto, ON, Canada, 2012.

23. BMC. Available online: https://systematicreviewsjournal.biomedcentral.com/articles/10.1186/2046-4053-4-1 (accessed on 21 July 2020).

24. Pussegoda, K.; Turner, L.; Garritty, C.; Mayhew, A.; Skidmore, B.; Stevens, A.; Boutron, I.; Sarkis-Onofre, R.; Bjerre, L.M.; Hróbjartsson, A.; et al. Systematic review adherence to methodological or reporting quality. Syst. Rev. 2017, 6, 131. [CrossRef] [PubMed]

25. Shamseer, L.; Weeks, L.; Turner, L.; Straus, S.; Grimshaw, J.; Moher, D. Identifying barriers to uptake and implementation of the CONSORT statement. In Proceedings of the Seventh International Congress on Peer Review and Biomedical Publication, Chicago, IL, USA, 8-10 September 2013.

26. Bardin, L. Análise de Conteúdo; Edições 70: São Paulo, Brazil, 2011; ISBN 978-85-62938-04-7. 
27. Burns, T. A helping hand: Education Responding to the Coronavirus Pandemic. OECD Education and Skills Today, 18 March 2020. Available online: https://oecdedutoday.com/education-responding-coronaviruspandemic/ (accessed on 21 July 2020).

28. OECD. Equity and Quality in Education: Supporting Disadvantaged Students and Schools; OECD Publishing: Paris, France, 2012.

29. González, R.; Wagenaar, J. Tuning Educational Structures in Europe; Final Report. Phase One; University of Deusto: Bilbao, Spain, 2003; ISBN 9788498303964.

30. Mesquita, D.; Lima, R.M.; Flores, M.A.; Marinho-Araujo, C.; Rabelo, M. Industrial Engineering and Management Curriculum Profile: Developing a Framework of Competences. Int. J. Ind. Eng. Manag. 2015, $6,121-131$.

31. Whitmore, P.G.; Fry, J.P. Soft Skills: Definition, Behavioral Model. Analysis, Training Procedures; Belvoir Defense Technical Information Center MAR: Fort Belvoir, VA, USA; Human Resources Research Organization: Alexandria, VA, USA, 1974.

32. Bennett, N.; Carré, C.; Dunne, E. Skills development in higher education and employment. In Differing Visions of a Learning Society; Policy Press: Bristol, UK, 2000; Volume 1.

33. Markes, I. A review of literature on employability skill needs in engineering. Eur. J. Eng. Educ. 2006, 31, 637-650. [CrossRef]

34. Lima, R.M.; Mesquita, D.; Rocha, C.; Rabelo, M. Defining the Industrial and Engineering Management Professional Profile: A Longitudinal Study Based on Job Advertisements. Production 2017, 27. [CrossRef]

35. Cruz, M.L.; Saunders-Smits, G.N.; Groen, P. Evaluation of competency methods in engineering education: A systematic review. Eur. J. Eng. Educ. 2019. [CrossRef]

36. Wieman, C.E. Expertise in University Teaching \& the Implications for Teaching Effectiveness, Evaluation \& Training. Dædalus 2019, 148, 47-78.

37. Vincent-Lancrin, S.; González-Sancho, C.; Bouckaert, M.; de Luca, F.; Fernández-Barrerra, M.; Jacotin, G.; Urgel, J.; Vidal, Q. Fostering Students' Creativity and Critical Thinking: What It Means in School; Educational Research and Innovation; OECD Publishing: Paris, France, 2019.

38. World Economic Forum. The Future of Jobs Employment, Skills and Workforce Strategy for the Fourth Industrial Revolution; Global Challenge Insight Report; World Economic Forum: Geneva, Switzerland, 2016.

39. World Economic Forum. The Future of Jobs Report; World Economic Forum: Geneva, Switzerland, 2018; ISBN 9781944835187.

40. Pegg, A.A.; Waldock, J.; Hendy-Isaac, S.; Lawton, R. Pedagogy for Employability; Learning and Employability Series; Higher Education Academy: Heslington, UK, 2006.

41. Owens, T.L. Higher education in the sustainable development goals framework. Eur. J. Educ. 2017, 52, 414-420. [CrossRef]

42. Giangrande, N.; White, R.M.; East, M.; Jackson, R.; Clarke, T.; Coste, M.S.; Penha-Lopes, G. A competency framework to assess and activate education for sustainable development: Addressing the UN sustainable development goals 4.7 challenge. Sustainability 2019, 11, 2832. [CrossRef]

43. Fraser, C.J.; Duignan, G.; Stewart, D.; Rodrigues, A. Overt and covert: Strategies for building employability skills of vocational education graduates. J. Teach. Learn. Grad. Employab. 2019, 10, 157-172. [CrossRef]

44. Woya, A.A. Employability among statistics graduates: Graduates' attributes, competence, and quality of education. Educ. Res. Int. 2019, 2019, 7285491. [CrossRef]

45. Verano-Tacoronte, D.; González-Betancor, S.M.; Bolívar-Cruz, A.; Fernández-Monroy, M.; Galván-Sánchez, I. Valoración de la competencia de comunicación oral de estudiantes universitarios a través de una rúbrica fiable y válida. Rev. Bras. Educ. 2016, 21,39-60. [CrossRef]

46. von Hauff, M.; Nguyen, T. Matching university graduates' competences with employers' needs in Taiwan. Int. Educ. Stud. 2015, 8, 122-133.

47. Backa, L.; Wihersaari, M. Future engineering education: What competences are energy companies looking for when recruiting graduates with a Master of Science (technology) degree? Eng. Educ. 2014, 9, 2-17. [CrossRef]

48. Jackson, D. Testing a model of undergraduate competence in employability skills and its implications for stakeholders. J. Educ. Work 2014, 27, 220-242. [CrossRef]

49. Moolman, H.J.; Wilkinson, A. Essential generic attributes for enhancing the employability of hospitality management graduates. Tourism 2014, 62, 257-276. 
50. Al-Mahrooqi, R.; Tuzlukova, V. English communication skills and employability in the Arabian Gulf: The case of Oman. Pertanika J. Soc. Sci. Humanit. 2014, 22, 473-488.

51. Del Arco, I.; Enciso, P. Instrumentales de Los Titulados Universitarios: Estudio Comparativo Evaluation of Instrumental Skills of University Graduates: A Comparative Study. Bordón 2011, 3, 91-105.

52. Nilsson, S. Enhancing individual employability: The perspective of engineering graduates. Educ. Train. 2010, 52, 540-551. [CrossRef]

53. Gokuladas, V.K. Technical and non-technical education and the employability of engineering graduates: An Indian case study. Int. J. Train. Dev. 2010, 14, 130-143. [CrossRef]

54. Hora, M.T.; Smolarek, B.B.; Martin, K.N.; Scrivener, L. Exploring the Situated and Cultural Aspects of Communication in the Professions: Implications for Teaching, Student Employability, and Equity in Higher Education. Am. Educ. Res. J. 2019, 56, 2221-2261. [CrossRef]

55. Prikshat, V.; Montague, A.; Connell, J.; Burgess, J. Australian graduates' work readiness—Deficiencies, causes and potential solutions. High. Educ. Ski. Work-Based Learn. 2019, 10, 369-386. [CrossRef]

56. Fraser, B. From Hospitality Classrooms to Successful Careers: A Current Appraisal of Australian International Hotel Requirements. J. Hosp. Tour. Educ. 2019. [CrossRef]

57. Lichy, J.; Khvatova, T. Rethinking solutions for re-balancing the education-job mismatch. J. Manag. Dev. 2019, 38, 733-754. [CrossRef]

58. Lopes, B.; Silva, P.; Melo, A.I.; Brito, E.; Dias, G.P.; Costa, M. The "lunar side" of the story: Exploring the sustainability of curricular internships in higher education. Sustainability 2019, 11, 5879. [CrossRef]

59. Asonitou, S.; Hassall, T. Which skills and competences to develop in accountants in a country in crisis? Int. J. Manag. Educ. 2019, 17, 100308. [CrossRef]

60. Tran, T.T.Q.; Admiraal, W.; Saab, N. Effects of critical incident tasks on the intercultural competence of English non-majors. Intercult. Educ. 2019, 30, 618-633. [CrossRef]

61. Cronin, L.; Allen, J.; Ellison, P.; Marchant, D.; Levy, A.; Harwood, C. Development and initial validation of the life skills ability scale for higher education students. Stud. High. Educ. 2019. [CrossRef]

62. Pais-Montes, C.; Freire-Seoane, M.J.; López-Bermúdez, B. Employability traits for engineers: A competencies-based approach. Ind. High. Educ. 2019, 33, 308-326. [CrossRef]

63. Rasiah, R.; Turner, J.J.; Ho, Y.F. The impact of emotional intelligence on work performance: Perceptions and reflections from academics in malaysian higher educationobitat endiaest que. Contemp. Econ. 2019, 13, 269-282.

64. Iglesias-Sánchez, P.P.; Jambrino-Maldonado, C.; de las Heras-Pedrosa, C. Training entrepreneurial competences with open innovation paradigm in higher education. Sustainability 2019, 11, 4689. [CrossRef]

65. Yao, C.W.; Tuliao, M.D. Soft skill development for employability: A case study of stem graduate students at a Vietnamese transnational university. High. Educ. Ski. Work-Based Learn. 2019, 9, 250-263. [CrossRef]

66. Cojocariu, V.M.; Cirtita Buzoianu, C.; Mares, G. Opportunities and Difficulties in Conducting Internships in Higher Education from the Employers' Perspective. Postmod. Open. 2019, 10, 1-27. [CrossRef] [PubMed]

67. Donald, W.E.; Baruch, Y.; Ashleigh, M. The undergraduate self-perception of employability: Human capital, careers advice, and career ownership. Stud. High. Educ. 2019, 44, 599-614. [CrossRef]

68. Ornellas, A.; Falkner, K.; Edman Stålbrandt, E. Enhancing graduates' employability skills through authentic learning approaches. High. Educ. Ski. Work-Based Learn. 2019, 9, 107-120. [CrossRef]

69. Ali, A.; Marwan, H. Exploring career management competencies in work based learning (WBL) implementation. J. Tech. Educ. Train. 2019, 11, 159-166. [CrossRef]

70. Bolívar-Cruz, A.; Verano-Tacoronte, D. Self-assessment of the oral presentation competence: Effects of gender and student's performance. Stud. Educ. Eval. 2018, 59, 94-101. [CrossRef]

71. Eta, E.A. Enhancing Graduate Employability in Cameroonian Universities through Professionalization in the Context of the 'Licence-Master-Doctorat' Reform. High. Educ. Policy 2018, 31, 309-332. [CrossRef]

72. Pineda-Herrero, P.; Ciraso-Cali, A.; Armijos-Yambay, M. Employable and competences of pedagogy, psychology, and educational psychology graduates: A comparative study of employers and graduates. Rev. Esp. Pedagog. 2018, 76, 313-333.

73. Sehgal, N.; Nasim, S. Total Interpretive Structural Modelling of Predictors for Graduate Employability for the Information Technology Sector. High. Educ. Ski. Work-Based Learn. 2018, 8, 495-510. [CrossRef] 
74. Chan, C.K.Y.; Fong, E.T.Y. Disciplinary differences and implications for the development of generic skills: A study of engineering and business students' perceptions of generic skills. Eur. J. Eng. Educ. 2018, 43, 927-949. [CrossRef]

75. Bautista-Mesa, R.; Molina Sánchez, H.; Ramírez Sobrino, J.N. Audit workplace simulations as a methodology to increase undergraduates' awareness of competences. Account. Educ. 2018, 27, 234-258. [CrossRef]

76. Sandri, O.; Holdsworth, S.; Thomas, I. Vignette question design for the assessment of graduate sustainability learning outcomes. Environ. Educ. Res. 2018, 24, 406-426. [CrossRef]

77. Sandri, O.; Holdsworth, S.; Thomas, I. Assessing graduate sustainability capability post-degree completion: Why is it important and what are the challenges? Int. J. Sustain. High. Educ. 2018, 19, 2-14. [CrossRef]

78. Moolman, H.; Africa, S. A conceptual competence-based framework for enhancing the employability of graduates. Indep. J. Teach. Learn. 2017, 12, 26-43.

79. Ishengoma, J.M. Incorporating the Tuning Approach in Higher Education Curricular Reforms and course Design in Tanzania for Enhancing Graduates' Competencies: Stakeholders' Views. Tuning J. High. Educ. 2017, 5, 121-169. [CrossRef]

80. Llanes Ordóñez, J.; Figuera Gazo, P.; Torrado Fonseca, M. Desarrollo de la empleabilidad y gestión personal de la carrera de graduados en Pedagogía/Employability and career management of graduates in Pedagogy. REOP Rev. Española Orientac. Psicopedag. 2017, 28, 46-60. [CrossRef]

81. Tsitskari, E.; Goudas, M.; Tsalouchou, E.; Michalopoulou, M. Employers' expectations of the employability skills needed in the sport and recreation environment. J. Hosp. Leis. Sport Tour. Educ. 2017, 20, 1-9. [CrossRef]

82. Jackson, D.; Wilton, N. Perceived employability among undergraduates and the importance of career self-management, work experience and individual characteristics. High. Educ. Res. Dev. 2017, 36, 747-762. [CrossRef]

83. Pinto, L.H.; Ramalheira, D.C. Perceived employability of business graduates: The effect of academic performance and extracurricular activities. J. Vocat. Behav. 2017, 99, 165-178. [CrossRef]

84. de Céspedes, B.R. Addressing employability and enterprise responsibilities in the translation curriculum. Interpret. Transl. Train. 2017, 11, 107-122. [CrossRef]

85. Álvarez-Álvarez, S.; Arnáiz-Uzquiza, V. Translation and interpreting graduates under construction: Do Spanish translation and interpreting studies curricula answer the challenges of employability? Interpret. Transl. Train. 2017, 11, 139-159. [CrossRef]

86. Schnell, B.; Rodríguez, N. Ivory tower vs. workplace reality: Employability and the T\&I curriculum-balancing academic education and vocational requirements: A study from the employers' perspective. Interpret. Transl. Train. 2017, 11, 160-186.

87. Yang, W. Tuning university undergraduates for high mobility and employability under the content and language integrated learning approach. Int. J. Biling. Educ. Biling. 2017, 20, 607-624. [CrossRef]

88. Sutherland, K.; Ho, S. Undergraduate perceptions of social media proficiency and graduate employability a pilot study. High. Educ. Ski. Work-Based Learn. 2017, 7, 261-274. [CrossRef]

89. Figueiredo, H.; Biscaia, R.; Rocha, V.; Teixeira, P. Should we start worrying? Mass higher education, skill demand and the increasingly complex landscape of young graduates' employment. Stud. High. Educ. 2017, 42, 1401-1420. [CrossRef]

90. Ayoubi, R.M.; Alzarif, K.; Khalifa, B. The employability skills of business graduates in Syria: Do policymakers and employers speak the same language? Educ. Train. 2017, 59, 61-75. [CrossRef]

91. Osmani, M.; Weerakkody, V.; Hindi, N. Graduate attributes in higher education: Examining academics' perception in the Middle East. J. Educ. Bus. 2017, 92, 53-64. [CrossRef]

92. O'Leary, S. Graduates' experiences of, and attitudes towards, the inclusion of employability-related support in undergraduate degree programmes; trends and variations by subject discipline and gender. J. Educ. Work 2017, 30, 84-105. [CrossRef]

93. Yang, H.; Cheung, C.; Song, H. Enhancing the learning and employability of hospitality graduates in China. J. Hosp. Leis. Sport Tour. Educ. 2016, 19, 85-96. [CrossRef]

94. Pineda-Herrero, P.; Agud-Morell, I.; Ciraso-Calí, A. Factores que Intervienen en la Inserción Laboral de los Titulados en Educación en Tiempos de Crisis: Un Estudio Sobre Cataluña; Revista de Educación $\mathrm{N}^{\circ}$ 372; Ministerio de Educación: Madrid, Spain, 2016; pp. 141-169. [CrossRef]

95. Piróg, D. The impact of degree programme educational capital on the transition of graduates to the labour market. Stud. High. Educ. 2016, 41, 95-109. [CrossRef] 
96. Xia, B.S.; Liitiäinen, E. Implications of Higher Education on Earnings. Int. J. Adult Vocat. Educ. Technol. 2016, 7, 50-64. [CrossRef]

97. Piróg, D. The role of competences for geography higher education in university-to-work transition. Geogr. Pol. 2016, 89, 221-236. [CrossRef]

98. Kaburise, P. Improving soft skills and communication in response to youth unemployment. Int. J. Afr. Renaiss. Stud. 2016, 11, 87-101. [CrossRef]

99. Feldmann, L. Considerations in the design of WBL settings to enhance students' employability: A synthesis of individual and contextual perspectives. High. Educ. Ski. Work-Based Learn. 2016, 6, 131-145. [CrossRef]

100. Perello-Marin, M.R.; Vidal-Carreras, P.I.; Marin-Garcia, J.A. What do undergraduates perceive about teamwork? Int. J. Eng. Educ. 2016, 32, 1171-1181.

101. Rodríguez, M.J.F.; Vicente, J.L.P.; Siles, G.G. Una experiencia en la vinculación universidad-empresa: El proyecto cogempleo de la fundación campus tecnológico de algeciras. Educ. XX1 2016, 19, 201-225.

102. Cavanagh, J.; Burston, M.; Southcombe, A.; Bartram, T. Contributing to a graduate-centred understanding of work readiness: An exploratory study of Australian undergraduate students' perceptions of their employability. Int. J. Manag. Educ. 2015, 13, 278-288. [CrossRef]

103. Donik, B.; Pajnkihar, M.; Bernik, M. Employability of Nursing Care Graduates. Organizacija 2015, 48, $287-297$. [CrossRef]

104. Torres-Coronas, T.; Vidal-Blasco, M.-A. Students and employers perception about the development of digital skills in higher education. Rev. Educ. 2015, 367, 63-89.

105. Fletcher-Brown, J.; Knibbs, K.; Middleton, K. Developing "employagility": The 3Es case for live-client learning. High. Educ. Ski. Work-Based Learn. 2015, 5, 181-195. [CrossRef]

106. Pujol-Jover, M.; Riera-Prunera, C.; Abio, G. Competences acquisition of university students: Do they match job market's needs? Intang. Cap. 2015, 11, 612-626. [CrossRef]

107. Tymon, A. The student perspective on employability. Stud. High. Educ. 2013, 38, 841-856. [CrossRef]

108. Del Peso, M.M.; Rabadán Gómez, A.B.; Hernández March, J. Desajustes Entre Formación y Empleo en el Ámbito de las Enseñanzas Técnicas Universitarias: La Visión de los Empleadores de la Comunidad de Madrid; Revista de Educación N 360; Ministerio de Educación: Madrid, Spain, 2013; pp. $244-267$.

109. Hennemann, S.; Liefner, I. Employability of german geography graduates: The mismatch between knowledge acquired and competences required. J. Geogr. High. Educ. 2010, 34, 215-230. [CrossRef]

110. Espinar, S.R.; Nebot, A.P.; Arjona, L.B.; Castiñeira, S.S. Sobre la empleabilidad de los graduados universitarios en Catalunya: Del diagnóstico a la acción. Rev. Educ. 2010, 351, 107-137. 